\title{
Recovery of rare earth elements from aqueous solution obtained from Vietnamese clay minerals using dried and carbonized parachlorella
}

\author{
Josiane Ponou ${ }^{1, *}$, Li Pang Wang $^{1}$, Gjergj Dodbiba $^{1}$, Katsunori Okaya ${ }^{1}$, Toyohisa Fujita ${ }^{1}$,
} Kohei Mitsuhashi ${ }^{2}$, Takafumi Atarashi ${ }^{2}$, Gouki Satoh $^{3}$, Masayoshi Noda ${ }^{3}$

${ }^{1}$ Department of Systems Innovation, Graduate School of Engineering, University of Tokyo, 7-3-1 Hongo, Bunkyo-ku, Tokyo 113-8656, Japan. Tel.: +81 3 5841 7077; Fax: +81 35841 7077.

${ }^{2}$ Nittetsu Mining Co.,Ltd, Research and Development department 8-1-Hirai-Hinode-machi, Nishitama-gun, Tokyo 190-0182 Japan

${ }^{3}$ Panac Advance Co., Ltd

OX Tamachi Bldg. 5-31-19, Shiba, Minato-Ku, Tokyo 108-0014, Japan. Tel: +81 35442

8782; Fax: +81354428148

*ponoujosiane21281@yahoo.co.jp

\section{Abstract}

The ongoing development of new advanced technologies, created increasing demands for rare earth elements (REEs) in the international market. The available conventional technologies for concentration and recovery of REEs are expensive making biosorption an efficient and low-cost technology for the recovery of REEs from aqueous solution. Thus, the biosorption and desorption of multi-component solution containing Y(III), La(III), $\mathrm{Sm}(\mathrm{III}), \mathrm{Dy}(\mathrm{III}), \operatorname{Pr}(\mathrm{III}), \mathrm{Nd}(\mathrm{III}), \mathrm{Gd}(\mathrm{III})$ were investigated using dried or $250^{\circ} \mathrm{C}$ and $350^{\circ} \mathrm{C}$ carbonized parachlorella. Evaluating the effect of $\mathrm{pH}$ with respect to contact time indicated 
22 a dependency of the system with those parameters. The optimum $\mathrm{pH}$ for dried and $250^{\circ} \mathrm{C}$

23 carbonized parachlorella was 7 whereas $350^{\circ} \mathrm{C}$ reaches it maximum uptake at $\mathrm{pH} 4$. Rapid

24 adsorption within the first 5 min of contact followed by a slight variation the following 20

25 min characterized the sorption processes onto parachlorella by-products. The mechanism of

26 the biosorption is explained by a combination of complex reactions occurring

27 simultaneously in the biosorption process.

28 In addition, desorption process has been investigated using various concentrations of $\mathrm{HCl}$,

$29 \mathrm{HNO}_{3}$, and $\mathrm{H}_{2} \mathrm{SO}_{4}$ at different temperatures. It was found that the reversible process is rapid,

30 less temperature and $\mathrm{pH}$ dependent with high desorption percentage. Moreover, only light

31 REEs were desorbed regardless of the kind of acid and the solution temperature.

32 Parachlorella is found to be good and low-cost biosorbent for the recovery of above REEs

33 from aqueous solutions.

34

35 Key-words: Rare earth, biosorption, recovery, carbonization, parachlorella

36

37 1. Introduction

38 Rare earth elements (REEs) are often referred as the "seeds of technology" because

39 of their uses in high-tech strength permanent magnets, lasers, automotive catalytic

40 converters, fiber optics/superconductors, electronic devices, and green energy sectors [1, 2].

41 Due to the ongoing development of new advanced technologies, there is an over-increasing

42 demand for REEs in the international markets, with emphasis on identifying new resources

43 to ensure adequate supply for present and future use. 
The designation "rare earths" refers to the 15 elements of the periodic table known

45 as "lanthanides" with yttrium and scandium, further divided as a function of their atomic

46 number into two categories. Light rare earth elements (LREE), which accounted for 66.8\%

47 of global demand in 2010 [2] referred to lanthanum, cerium, praseodymium, neodymium,

48 promethium and samarium. Heavy rare earths elements (HREE), less common and more

49 valuable, referred to the rest of lanthanides elements with yttrium. The 17 REEs are found

50 in all REE geological deposits because they share many similar properties but their

51 distribution and concentrations vary [2]. REE mineral deposits are usually rich in either

52 LREE or HREE, but rarely contain both in significant quantities [2]. The term "rare earth"

53 is actually a misnomer, because these elements are more abundant in the earth's crust

54 compared to silver, gold or the platinum-group metals and are part of more than 200 rock-

55 forming minerals $[1,3]$. They are "rare" because they do not naturally occur in metallic

56 form, only as mixed and scattered in minerals and are difficult to separate from each other

57 due to very similar physico-chemical properties [1].

58 Several expensive methods exist to recover REEs from ores such as pyrometallurgy,

59 hydrometallurgy etc processes in case of REEs rich ores. In addition, different methods

60 have been proposed for separation and preconcentration of REEs such as precipitation,

61 liquid-liquid extraction, solid-liquid extraction, super critical extraction, electro-winning,

62 electro-refining, etc [4-7] but, those methods are inefficient or required a large volume of

63 solvent or intensive labor [7-9]. Thus, find a low-cost and efficient technology for the

64 concentration and recovery of REEs led to the choice of biosorption. Some biomasses such

65 as pseudomonas aeruginosa, saccharomyces cerevisiae etc have been tested [10-11] and 
66 found efficient for the recovery of Dy(III), Sc(III), La(III), $\operatorname{Pr}(\mathrm{III}), \mathrm{Nd}(\mathrm{III}), \quad \mathrm{Eu}(\mathrm{III})$.

67 However, due to the large number of candidate biomasses, biosorption of REEs need to be

68 deepened and more biomasses need to be tested.

69 Therefore, in this study parachlorella, an alga used by PANAC Co. Ltd to enhance

70 the bio-energy production efficiency, was used as biosorbent. In addition, a solution of

71 REEs containing a mixture of Y(III), La(III), Sm(III), Dy(III), Pr(III), Nd(III) Gd(III)

72 under various concentrations was prepared from Vietnamese rare earth ore and used for the

73 experiment. Thus, In order to improve the sorption efficiency of parachlorella, the alga is

74 carbonized at $250^{\circ} \mathrm{C}$ and $350^{\circ} \mathrm{C}$ and the REEs uptake of carbonized parachlorella is

75 compared to the dried one. Desorption process was also evaluated and the mechanism 76 clearly described.

77

78 2. Materials and Methods

$79 \quad 2.1$ Equipments

80 Thermo gravimetric differential thermal analysis (TG-DTA) (Thermo plus EVO TG

81 8120/ Rigaku) was carried out under nitrogen condition. The carbonization of parachlorella

82 was made out using electric furnace (HPM-OG/AS ONE). The surface texture of the

83 biosorbent before and after experiment was investigated using SEM (Scanning electron

84 microscope JSM-6510LA/JEOL). The zeta potential was measured by electrophoresis

85 analysis (LS-2000E/ Photal OTSUKA Electronic). The reciprocal shaking bath (FTB-

86 01/AS ONE) was used for the batch experiment process. The $\mathrm{pH}$ of the solution was

87 measured with $\mathrm{pH}$ meter (HM-25R/ TDA DK) previously calibrated. The REEs content in 
treated solution was analyzed using ICP-OES (Inductively coupled plasma-optimal emission spectrometer /Perkin Elmer/Optima 5300). In order to point out the structure of the biosorbents and the functional group involved in the adsorption process Fourier transform infrared spectrometer (FT/IR 4100/DR410/ATR PRO 450-S) was used.

\subsection{Biosorbents preparation}

Parachlorella was received from Panac. Co. Ltd in dried form (the sample was subject to spray dried for 3 days). One part of the material is subjected to the thermal decomposition analysis under $\mathrm{N}_{2}$ atmosphere (decomposition rate $10^{\circ} \mathrm{C} / \mathrm{min}$ ) on TG-DTA in order to point out the optima temperatures at which the carbonization should be made up. As results, the dried parachlorella was carbonized at $250^{\circ} \mathrm{C}$ or $350^{\circ} \mathrm{C}$ in the electric furnace, for $30 \mathrm{~min}$. The heated was done under $\mathrm{N}_{2}$ atmosphere (gas flow: 15L/min) to avoid any oxygenation during the carbonization. Then the carbonized materials are desiccated until there are completely cooled. The sample was then sieved to obtain a fraction of fine particles all passing $0.6 \mathrm{~mm}$.

\subsection{Batch experiments}

A solution containing the mixture of $\mathrm{Y}(\mathrm{III}), \mathrm{La}(\mathrm{III}), \mathrm{Sm}(\mathrm{III}), \mathrm{Dy}(\mathrm{III}), \mathrm{Pr}(\mathrm{III}), \mathrm{Nd}(\mathrm{III})$, $\mathrm{Gd}(\mathrm{III})$ rare earth ions and others elements as $\mathrm{Mg}, \mathrm{Si}, \mathrm{K}, \mathrm{Ca}, \mathrm{Mn}$, and $\mathrm{Fe}$ in diverse concentrations and initial $\mathrm{pH}=5.63$ at $30^{\circ} \mathrm{C}$ is shown in Fig. 1. This solution was prepared by dissolving the Vietnamese rare earth ore in 2 wt $\%$ of ammonium sulfate aqueous solution. The mixture was kept for $60 \mathrm{~h}$ under room conditions. This aqueous solution (Fig.1) was used as an initial one for the batch experiments. 
110 Batch studies were conducted to investigate the parametric factors such as $\mathrm{pH}$, solution

111 temperature, biosorbent dosage and contact time for both biosorption and desorption 112 processes. The $\mathrm{pH}$ of the solution was adjusted using $1 \mathrm{~mol} / \mathrm{L}$ of $\mathrm{HCl}$ or $\mathrm{NH}_{3}$ aqueous 113 solution. The biosorbent was then mixed with REEs aqueous solution, resulting to the 114 concentration of $5 \mathrm{~g} / \mathrm{L}$. The mixture was then shaken in the bath at $30^{\circ} \mathrm{C}$ and $150 \mathrm{rpm}$. The 115 sample was filtered with $0.2 \mu \mathrm{m}$ filter and the filtrate was analyzed using ICP-OES in terms 116 of remaining REEs and others elements concentration. The amount of REEs or others 117 elements adsorbed $q(\mathrm{mg} / \mathrm{g})$ was calculated by using the following equation

$118 \quad q=\frac{V\left(C_{\text {int }}-C_{\text {fin }}\right)}{M}$

$119 V \quad$ Volume of the solution (L)

$120 \quad M \quad$ Mass of the biosorbent used $(\mathrm{g})$

$121 C_{\text {init }} \quad$ Initial REEs or others common ions concentration $(\mathrm{mg} / \mathrm{L})$

$122 C_{f i n} \quad$ Final concentration of rare earth ions or others common ions in solution $(\mathrm{mg} / \mathrm{L})$

123 The percentage of removed rare earth ions or others was interpreted as:

125 Removal $(\%)=\frac{\mathrm{C}_{\text {init }}-\mathrm{C}_{\mathrm{fin}}}{\mathrm{C}_{\text {init }}}$

$128100 \mathrm{~mL}$ of REEs solution into contact for 2 hours (to saturate as much as possible the 129 available biosorbents sites with rare earth ions). The biosorption process was conducted at $130 \mathrm{pH} 7$ and $30^{\circ} \mathrm{C}$ until equilibrium was reached. The solution was analyzed using ICP-OES 
131 and equation (1) helps to determine the desorption density at equilibrium $q_{o}$ for the selected

132 biosorbents. The REEs loaded samples, which will be subjected to desorption experiment 133 were dried in the oven at $80^{\circ} \mathrm{C}$ for 72 hours.

$1340.05 \mathrm{~g}$ of the prepared sample was mixed with $10 \mathrm{~mL}$ of $\mathrm{HCl}, \mathrm{HNO}_{3}, \mathrm{H}_{2} \mathrm{SO}_{4}$ 135 (various concentration of acid have been used) and shaken at various temperatures 136 depending on the parameter study. The solution obtained was analyzed using ICP-OES and 137 the results obtained were interpreted in terms of total REE recovery

$$
q(X)=\frac{C \cdot V(X)}{M_{a}}
$$

$139 X$ represents $\mathrm{HCl}, \mathrm{HNO}_{3}$, or $\mathrm{H}_{2} \mathrm{SO}_{4}$

$140 V(X)$ volume of $\mathrm{HCl}, \mathrm{HNO}_{3}$, or $\mathrm{H}_{2} \mathrm{SO}_{4}$ solution

$141 C$ concentration of REE in the solution after desorption process was achieved

$142 M$ weight of the de-sorbent used

144 expressed as

145 Desorbed $\%(X)=\frac{q(X)}{q_{0}} .100$

\section{3. Results and discussions}

\section{$147 \quad 3.1$ Biosorbents characteristics}


As organic material, parachlorella is mainly composed of hemicelluloses, cellulose, 149 lignin and others minerals [12]. The thermal decomposition of parachlorella can therefore 150 be attributed to the decomposition of these macromolecules, which is accompanied by the 151 release of volatile matters from the raw material.

152 Generally, carbonization also called slow pyrolysis or conventional pyrolysis, is 153 characterized by a slow heating rate $\left(6-60^{\circ} \mathrm{C} / \mathrm{min}\right)$, and the formation of pyrolysis product 154 occurs in the temperature range of $275-675^{\circ} \mathrm{C}$ [13]. The first stage of biomass 155 decomposition, also called prepyrolysis stage, occurs at $120-200^{\circ} \mathrm{C}$. During this stage, some 156 internal molecular rearrangements such as water elimination, bond breakage, appearance of 157 free radicals, and the formation of carbonyl, carboxyl and peroxide (ROOR') groups take 158 place [13]. The second stage mainly involves the decomposition of solid biomass, which is 159 associated with high rate of transformation and formation of pyrolysis product. During the 160 third stage, the char decomposes at a very slow rate, forming a carbon-rich residual solid 161 [13].

162 Many researchers have worked on the thermal decomposition of cellulose, 163 hemicelluloses and lignin. For instance, it was previously reported that the decomposition 164 of cellulose occurs in a flexible range of $200-400^{\circ} \mathrm{C}$, lignin decomposed in the range of $165 \quad 150-750^{\circ} \mathrm{C}\left(900^{\circ} \mathrm{C}\right.$ as maximum $)$. Characterized by low thermal stability, hemicellulose is 166 decomposed in the range $180-240^{\circ} \mathrm{C}[14-15]$.

167 The weight loss measurement of parachlorella can be well understood by 168 considering the rate of raw material transformed (burned) with increasing temperature 169 calculated from equation 5. 
$170 \propto=\frac{W_{T}}{W_{b}}$

171 where, $W_{T}, W_{b}$ are respectively the weight of solid (dried) burned at temperature $T$ and the

172 total weight of solid burned during the pyrolysis process.

173 In other world, $\alpha$ represents the rate of volatile matter release from the raw material with

174 increasing elementary temperature. $\alpha$ was calculated from the weight loss data obtained

175 with TG-DTA analysis. Fig. 2 shows the experimental results of $\alpha$ vs. $T$.

176 It should be noted that, due to TG-DTA machine program setting, thermograms of $\alpha$

177 vs. $T$ in Fig. 2 show two curves which were due to the machine programming system. The

178 machine is settled to burn once time and re-burns at the same temperature that justifies the

179 two curves. The highest curve represents the amount of volatile matters release from the

180 material after the first thermal decomposition and the lowest one deal with the second

181 burning operation. Moreover, $\alpha$ increases to a peak at around $300^{\circ} \mathrm{C}$ and then decreases

182 with increasing temperature until $400^{\circ} \mathrm{C}$ whereby stability is observed.

183 Furthermore, Fig. 2 highlights that the prepyrolysis states of dried parachlorella

184 occurred in the range $0-200^{\circ} \mathrm{C}$ were weight loss was comparatively low. From $200^{\circ} \mathrm{C}$, the 185 decomposition increased rapidly to a maximum at $300^{\circ} \mathrm{C}$. Thus, parachlorella, 186 decomposition of macromolecules may occur within $200^{\circ} \mathrm{C}-300^{\circ} \mathrm{C}$. Beyond $300^{\circ} \mathrm{C}$, 187 however, the transformation rate decreased progressively until $400^{\circ} \mathrm{C}$, implying that 188 carbon-rich material may be formed in the range of $300-400^{\circ} \mathrm{C}$ with slow rate of 189 gasification. Hence, there seems to be an optimal decomposition temperature at which 190 carbon rich material is formed. Then the carbonization temperatures have been set at $250^{\circ} \mathrm{C}$ 
191 or $350^{\circ} \mathrm{C}$ to better understand the transformation occurring before and after the main peak

192 of Fig. 2. Further experiments were carried out using three kinds of biosorbents: dried 193 parachlorella (PA); $250^{\circ} \mathrm{C}$ carbonized parachlorella (PA250); $350^{\circ} \mathrm{C}$ carbonized 194 parachlorella (PA350).

195 PA, PA250 and PA350 were subjected to FT-IR analysis in order to understand the 196 functional groups governing the biosorbents. Results are summarized in Fig. 3. Fig.3 shows 197 that PA, PA250, and PA350 present different shapes. This should be due to the 198 carbonization process that shifts the functional group of the original dried biosorbent to 199 others more active functional groups [16]. The presence of carbonyl groups on the surface 200 of the biosorbents at the wave numbers $1676 \mathrm{~cm}^{-1}$ and $1707 \mathrm{~cm}^{-1}$ for PA, $1707 \mathrm{~cm}^{-1}, 1710$ $201 \mathrm{~cm}^{-1}$ and $1711 \mathrm{~cm}^{-1}$ for PA250 and $1688 \mathrm{~cm}^{-1}$ for PA350 $\mathrm{cm}^{-1}$ may be helpful in the 202 biosorption processes. In the carbonyl group, oxygen is more electronegative than carbon 203 and then, can picks over electron density from carbon to increase the bond polarity. Thus, 204 the carbon of the carbonyl group becomes electrophilic (able to react with anions in 205 solution). In the same way, electronegative oxygen can react with cations. Moreover, 206 phosphorus compound, which main element is phosphorous, is recognized as a highly 207 electronegative group reacted as nitrogen since they belong to the same chemical group.

208 In addition, X-ray fluorescence (XRF) was used to determine the chemical 209 composition of dried and carbonized parachlorella. The results are shown in Table 1. XRF 210 analysis detects the presence of chemicals except $\mathrm{C}, \mathrm{O}$ and $\mathrm{H}$. Parachlorella by-products are 211 mainly composed on $\mathrm{P}, \mathrm{S}, \mathrm{K}, \mathrm{Ca}$ and $\mathrm{Mg}$. The presence of cations $\mathrm{K}^{+}, \mathrm{Mg}^{2+}$ and $\mathrm{Ca}^{2+}$ may 212 be helpful in ion exchange process [17]. 
214 have been carried out and shown in Fig. 4. Dried parachlorella compared to carbonized one

215 looks like a block. This block has been altered by the temperature since small pores 216 appeared. Carbonization may increase the porosity of parachlorella by opening new pores 217 or deepen existing pores [18].

\subsection{Effect of pH on REEs removal}

$\mathrm{pH}$ is one of the most important and predominant factors to be considered when

221 assessing the biosorption capacity of an biosorbent as it influences the biomass adsorptive

222 sites as well as the solution chemistry of REEs. The $\mathrm{pH}$ of the system controls the sorption

223 capacity due to its influence on the surface properties and metal speciation [19]. The

224 sorption experiments were carried out in the $\mathrm{pH}$ range 1-10 while keeping other parameters

225 constant. $1 \mathrm{~mol} / \mathrm{L}$ of $\mathrm{HCl}$ or ammonia (because of the use of ICP-OES which does not show

226 reliable results when $\mathrm{Na}$ concentration is high in the analysis solution) solution were used

227 for the $\mathrm{pH}$ adjustments. Precipitation of the solution of rare earth ions, with rapid deposit is

228 observed at $\mathrm{pH}$ higher than 7 due to the formation of hydroxide forms of rare earth ions

229 which become dominant. Consequently, the $\mathrm{pH}$ effect on parachlorella by-products was

230 conducted in the batch in the $\mathrm{pH}$ range 1-7 for 1hour. Results are shown in Fig.5. Zeta

231 potential of PA, PA250, and PA350 were also investigated and results are shown in Fig.6.

232 Fig.5 indicated that, at strong acidic $\mathrm{pH}(\mathrm{pH}$ range 1-3), rare earth ions uptake is

233 inhibited for PA, PA250 and PA350 as shown by earlier researchers [20-22]. The low

234 uptake observed at strong acidic values may be explained by the protonation of biosorbents 
235 sites with $\mathrm{H}^{+}$ions. Fig. 6 justifies this assumption. Consequently, the majority of binding 236 sites were occupied and rare earth cations may not be able to compete with hydronium 237 cations in occupying sites due to the repulsion forces created between same positively 238 charged ions [23].

239 As pH increased, surface positive charges decrease, leading to interaction between 240 positively charged rare earth ions and negatively charged biosorbent sites [20] (Fig.6). PA 241 and PA250 reached their maximum uptake of rare earth ions at $\mathrm{pH} 7$ whereas PA350 242 increases until $\mathrm{pH}$ around 4 and decreases again.

As we described in the precedent sections, carbonyl functional group may be 244 presents in $350^{\circ} \mathrm{C}$ carbonized parachlorella. The maximum uptake of rare earth ions 245 observed at pH 4 using PA350 may be explained by the reaction of carbonyl functional 246 group which pKa values lies around 4.8 [24]. Moreover, the point of zero charge of PA350 247 is close to $\mathrm{pH} 4.5$ (Fig. 6). We can conclude that $\mathrm{Y}^{3+}, \mathrm{La}^{3+}, \mathrm{Sm}^{3+}, \mathrm{Dy}^{3+}, \mathrm{Pr}^{3+}, \mathrm{Nd}^{3+}, \mathrm{Gd}^{3+}$ are 248 the dominant species at $\mathrm{pH}$ less than 4.5. Those species shift to hydrolyzed forms as $249 \mathrm{Y}(\mathrm{OH})^{2+,} \quad \mathrm{La}(\mathrm{OH})^{2+}, \quad \mathrm{Sm}(\mathrm{OH})^{2+}, \quad \mathrm{Dy}(\mathrm{OH})^{2+}, \quad \operatorname{Pr}(\mathrm{OH})^{2+}, \quad \mathrm{Nd}(\mathrm{OH})^{2+}, \quad \mathrm{Gd}(\mathrm{OH})^{2+}$ or 250 dihydrolyzed rare earth ions $\mathrm{Y}(\mathrm{OH})_{2}{ }^{+}, \mathrm{La}(\mathrm{OH})_{2}{ }^{+}, \mathrm{Sm}(\mathrm{OH})_{2}{ }^{+}, \mathrm{Dy}(\mathrm{OH})_{2}{ }^{+}, \operatorname{Pr}(\mathrm{OH})_{2}{ }^{+}$, $251 \mathrm{Nd}(\mathrm{OH})_{2}{ }^{+}, \mathrm{Gd}(\mathrm{OH})_{2}{ }^{+}$or trihydrolyzed rare earth ions $\mathrm{Y}(\mathrm{OH})_{3}, \mathrm{La}(\mathrm{OH})_{3}, \mathrm{Sm}(\mathrm{OH})_{3}$, $252 \mathrm{Dy}(\mathrm{OH})_{3}, \operatorname{Pr}(\mathrm{OH})_{3}, \mathrm{Nd}(\mathrm{OH})_{3}, \mathrm{Gd}(\mathrm{OH})_{3}$ or the mixture of the three hydrolyzed forms [21, $25325]$.

For PA and PA250 the maximum uptake of rare earth ions observed at $\mathrm{pH} 7$ may be 255 explained by the electrostatic interaction between rare earth trivalent ions and biosorbent 256 surface charge which is negatively charged (Fig.6). 
Moreover selectivity in terms of ions uptake and type of biosorbent is observed at 258 optimum $\mathrm{pH}$. Consequently, PA and PA250 are found to be more efficient for biosorption 259 of Sm and La than PA350. PA is more efficient for Pr and Nd than others biosorbents. 260 PA250 is the best biosorbents for $\mathrm{Dy}, \mathrm{Gd}$, and $\mathrm{Y}$. Then, the following experiments are done 261 base on the optimum $\mathrm{pH}$ observed for PA and PA250, means $\mathrm{pH} 7$.

\subsection{Effect of contact time and possible biosorption mechanism}

REEs uptake onto PA, PA250 and PA350 was investigated with respect to contact

265 time in the range of 0-120 min, while keeping other parameters constant. Fig. 7 shows the 266 effect of contact time for PA, PA250 and PA350 at pH 7, keeping the biosorbent dosage to $2675 \mathrm{mg} / \mathrm{L}$. For all the biosorbents, a rapid uptake of REEs ions was observed during the first 5 268 min followed by a slight variation of uptake rate until $20 \mathrm{~min}$. As expected, PA and PA250 269 show the best results compared to PA350. It is difficult to distinguish the best biosorbent in 270 this experiment since selectivity is observed depending on the sorbate. For example, PA is 271 good biosorbents for Nd than PA250 whereas PA250 is efficient for La than PA. This 272 should be due to the affinity of each sorbate to react with each biosorbents than others. For 273 better understanding of the mechanism of the biosorption system, kinetics of the others ions 274 such as $\mathrm{Si}, \mathrm{Fe}, \mathrm{Mn}, \mathrm{Mg}, \mathrm{K}$ and Ca present in the Vietnamese ores solution was evaluated. 275 Those concentrations have been compared to their initial ones. Results are shown in Fig.8. 276 Fig. 8 shows that concentrations of $\mathrm{Si}, \mathrm{Fe}, \mathrm{Mn}$ and $\mathrm{Ca}$ were stable before and after

277 biosorption process. However, $\mathrm{Mg}$ and $\mathrm{K}$ concentrations increased after sorption for PA 278 and PA250 and only concentration of $\mathrm{K}$ increases after sorption for PA350 meaning that 
only rare earth ions are adsorbed on parachlorella species selectively during the biosorption processes. As the XRF results of parachlorella by-products have shown, $\mathrm{Mg}, \mathrm{K}$ are also presents in the sorbents. Then the increase of $\mathrm{Mg}$ and $\mathrm{K}$ concentration in the solution may be due to the dissolution of those elements present on the surface of biosorbents during the biosorption process. Authors suspect a kind of ion exchange between rare earth ions in the solution and $\mathrm{Mg}, \mathrm{K}$ present on the surfaces of biosorbents. Then, mechanisms involved in biosorption of Vietnamese ores solution using parachlorella should be a complex process composed of many reactions occurring simultaneously in the system biosorbent-sorbates: electrostatic forces between rare earth ions and surface charges, biosorption of the tested rare earth ions onto the active functional groups of biosorbents, and ion-exchange process as described by Das et al. [26]. In addition, since the presence of hydroxide forms of rare earth ions were pointed out, sorption of REEs onto parachlorella species may also due to surface complexation reactions of parachlorella species forming $\mathrm{M}-\mathrm{O}-\mathrm{Ln}^{2+} \cdot \mathrm{M}$ designated the biosorbents used (PA, PA250, and PA350) and Ln represents rare earth ions.

\subsection{Adsorption kinetics}

Adsorption kinetics describes the solute uptake rate as a function of residence time of adsorbate at the solid-liquid phase including the diffusion process [16]. The kinetic rate of REE ions was investigated using the pseudo first-order and pseudo second-order model [27]. The agreement between experimental data and models as depicted by the values of their correlation coefficients $\left(R^{2}\right)$ are summarized in Table 2. The pseudo first-order kinetic model is described by (Eq.6) 
$302 \log \left(\mathrm{q}_{\mathrm{e}}-\mathrm{q}_{\mathrm{t}}\right)=\log \mathrm{q}_{\mathrm{e}}-\mathrm{t} \cdot \mathrm{k}_{1} / 2.303$

303

304 The pseudo second-order kinetic model is expressed as (Eq.7):

$305 \frac{t}{q_{t}}=\frac{1}{\left[k_{2} q_{e} 2\right]}+\frac{t}{q_{e}}$

$306 K_{l} \quad$ Pseudo first-order kinetic equilibrium rate constant

$307 \quad K_{2} \quad$ Pseudo second-order kinetic equilibrium rate constant $(\mathrm{mg} / \mathrm{g} / \mathrm{min})$

$308 q_{e} \quad$ Amount adsorb per gram of the biosorbent at equilibrium $(\mathrm{mg} / \mathrm{g})$

$309 q_{t} \quad$ Amount adsorb per gram of the biosorbent at time $t(\mathrm{mg} / \mathrm{g})$

$310 t \quad$ Contact time ( $\mathrm{min})$

Fig.9 represents the plots $t / q_{t}$ vs. $t$ of PA at the indicated experimental 312 conditions. Table 2 shows the values of the kinetics. The correlation coefficients for the 313 pseudo second-order kinetic model shows a much better fit compared with the coefficients 314 derived from the pseudo first-order kinetic model, suggesting that the biosorption of REE 315 ions onto PA, PA250 and PA350 follow the pseudo second-order kinetic model. Moreover, 316 the experimental values of the biosorbents densities at equilibrium $q_{e}$ are compared to the 317 calculated values of the equilibrium densities $q_{e 1 c a l c}$ and $q_{\text {e2calc }}$ (Table 2) respectively the 318 equilibrium density calculated using equations (6) and (7). The close or small difference 319 between the values of $q_{e}$ and $q_{e 2 c a l c}$ further confirmed the fitness of pseudo second-order 320 kinetic model with experimental data. The biosorption reaction rate is then limited to the 321 rate of the rare earth ions diffusion in the pores. 


\section{$323 \quad 3.5$ Adsorption activation energy and enthalpy of activation}

327 The parameters $k$ and $E_{a}$ called Arrhenius parameters characterized (Eq.8). The pre328 exponential factor $K$ or the frequency factor indicates the rate at which collisions occur.

329 The activation energy $E_{a}$ is the minimum kinetic energy required for the reaction during the 330 molecular collision [28].

$331 \quad k \quad$ The pre-exponential factor or frequency factor $(\mathrm{g} / \mathrm{mg} / \mathrm{min})$

$332 \quad E_{a} \quad$ The activation energy of sorption $(\mathrm{J} / \mathrm{mol})$

$333 \quad R \quad$ The gas constant $(8.314 \mathrm{~J} / \mathrm{mol} / \mathrm{K})$,

$334 \quad T \quad$ The solution temperature $(\mathrm{K})$

Arrhenius equation parameters were evaluated using the pseudo second-order

336 kinetic constant obtained based on temperature controlled data $\left(30^{\circ} \mathrm{C}, 50^{\circ} \mathrm{C}, 70^{\circ} \mathrm{C}\right)$.

337 Sorption of REEs onto parachlorella species increases with temperature showing the

338 temperature dependency of the process. The value of activation energy is obtained by using

339 the pseudo second-order kinetic equilibrium rate constant $k_{2}$ obtained at each temperature.

340 A plot of $\ln k_{2}$ vs. $1 / T$ yields a straight line with a slope $-E_{a} / R$. Generally, the value of 341 activation energy is used to distinguish physical and chemical sorption. Physical sorption is 342 characterized by low energy whereas chemical sorption involves stronger forces needed for 343 the formation of external bonding [16]. 
347 It can be concluded from Table 3 that $\mathrm{Y}^{3+}, \mathrm{La}^{3+}, \mathrm{Sm}^{3+}, \mathrm{Dy}^{3+}, \mathrm{Pr}^{3+}, \mathrm{Nd}^{3+}$, and $\mathrm{Gd}^{3+}$ are 348 chemically adsorbed onto dried and carbonized parachlorella and the tested rare earth ions 349 are adsorbed under endothermic reactions. However, the real nature (chemisorption and 350 endothermic) of the systems (Dy, PA); (Dy, PA250) and (Y, 250) was not clearly 351 determined due to their low adsorption densities.

352

\section{$353 \quad 3.6$ Adsorption isotherms}

354 Sorption density of PA, PA250 and PA350 as a function of biosorbent dosage was 355 investigated in the biosorbent dosage range of 1-250 $\mathrm{g} / \mathrm{L}$ while keeping $\mathrm{REE}$ initial 356 concentration constant. The amount of adsorbed REE ions increased with increasing 357 biosorbent dosage, emphasizing the dependency of biosorption density of the system on the 358 biosorbent dosage.

359 In order to describe the interactive relationship between biosorbent and adsorbate 360 and design the biosorption system, Langmuir model was examined using (Eq.10)

$$
\frac{C_{e}}{q_{e}}=\frac{1}{b \cdot q_{\max }}+\frac{C_{e}}{q_{\max }}
$$

$362 \quad C_{e} \quad$ REE concentration in solution at equilibrium $(\mathrm{mg} / \mathrm{L})$

$363 q_{e} \quad$ Amount adsorb per gram of the biosorbent at equilibrium $(\mathrm{mg} / \mathrm{g})$

$364 \quad b \quad$ Langmuir constant $(\mathrm{L} / \mathrm{mg})$

$365 q_{\max } \quad$ Maximum adsorption capacity $(\mathrm{mg} / \mathrm{g})$ 
367 molecules. As can be seen in Table 4, Langmuir isotherm model fitted well the 368 experimental data and the best densities with carbonized materials were observed with $369250^{\circ} \mathrm{C}$ carbonized materials demonstrating the importance of low carbonization temperature 370 on parachlorella. Results obtained in this work are lower compared to the ones of Oliviera 371 et al. [17]. Many parameters affect the biosorption process that creates a discrepancy in 372 experimental results. In multi-components solution, all sorbates compete for a single 373 population of surface sites and interact each other. In that case competitive Langmuir 374 adsorption occurs [29]. For example in a solution containing only one sorbate, the relation 375 between the biosorption density at equilibrium and the maximum one is expressed as:

$$
\frac{q_{e}}{q_{\max }}=\frac{b C_{e}}{1+b C_{e}}
$$

377 Generalizing the above result to the case where $\mathrm{j}$ sorbates compete for the site we obtained:

$$
\frac{q_{e i}}{q_{\max }}=\frac{b_{i} C_{e i}}{1+\sum_{a l l j} b_{j} C_{e j}}
$$

(Eq. 12) explained the low $q_{\max }$ obtained for the rare earth elements ions studied in the present work. The numerator of (Eq. 12) is the same of the one of (Eq. 11), and the 381 denominator of (Eq. 12) depends on the number of sorbates present in the system. Then 382 each additional sorbate in the solution increases the denominator of (Eq. 12) then decreases 383 the amount of $\mathrm{i}$ adsorbed. As would be expected, the larger the activity of the competing 384 sorbates and the greater their tendency to adsorb, and the larger is their effect on sorption 385 [29]. Oliviera et al. used a mono-component and binary component solution for their 386 experiments explaining their results. 


\subsection{Recovery of REES}

The recovery of adsorbed REEs is an important step to obtain the metals in their pure forms. Desorption process may help to decrease the operating cost and diminish the dependency to continual supply of the biosorbents. Thus, more the desorption percentage is high more the process is efficient and biosorbent useful [30-32]. Desorption processes has been studied using various concentrations $(0.1,0.5,1 \mathrm{~mol} / \mathrm{L})$ of $\mathrm{HCl}, \mathrm{HNO}_{3}, \mathrm{H}_{2} \mathrm{SO}_{4}$ at different temperatures $\left(30^{\circ} \mathrm{C}, 50^{\circ} \mathrm{C}, 70^{\circ} \mathrm{C}\right)$. Results are shown in Tables 5 and 6. by-products may occur at acidic $\mathrm{pH}$. Variation of acid concentration affected the solution $\mathrm{pH}$. Results have proved that $\mathrm{pH}$ (Table 5) as well as temperature (Table 6) have slight effect on the desorption percentage. However selectivity is observed. Dysprosium and gadolinium were not desorbed by acid neither with variation of $\mathrm{pH}$ nor with increasing temperature. Coppin et al.[33] related this behavior to the "lanthanide contraction" in the

401 ionic radii going from light to heavy REEs. The effective ionic radii from lighter to heavier 402 REEs are 90, 103.2, 99, 98.3, 95.8, 93.5, 91.2 pm respectively for $\mathrm{Y}^{3+,} \mathrm{La}^{3+}, \mathrm{Pr}^{3+}, \mathrm{Nd}^{3+}$, $403 \mathrm{Sm}^{3+}, \mathrm{Gd}^{3+}$, and $\mathrm{Dy}^{3+}$. According to the results obtained in Table 5 and 6 we can then 404 conclude that desorption is more due to the molecular weight than the ionic radii. The 405 lighter metals are easy to be desorbed than the heavier. 
results are quite related with the ones obtained by Moldoveanu [1]. The high and rapid desorption rate obtained demonstrates the good efficiency of the method and since low-cost biosorbents are used, the process is low-cost and can be employed to recover REEs from ores aqueous solutions or sewage.

\section{Conclusions}

The present study investigated the biosorption/desorption of, Y(III), La(III), Sm(III), Dy(III), $\operatorname{Pr}(\mathrm{III}), \mathrm{Nd}(\mathrm{III}), \mathrm{Gd}(\mathrm{III})$ present under various concentration in Vietnamese ores aqueous solution, onto dried and $250^{\circ} \mathrm{C}$ and $350^{\circ} \mathrm{C}$ carbonized parachlorella. Experiments performed as function of solution $\mathrm{pH}$ and contact time revealed that biosorption of above cited rare earth are highly dependent on those parameters. Moreover the uptake of rare earth ions was inhibited at low $\mathrm{pH}$ due to the protonation of the biosorbents sites. Selectivity of rare earth ions for one biosorbent than others characterized the biosorption process which was found rapid. The mechanism of the biosorption processes is explained by the combination of four reactions; electrostatic interaction between rare earth ions and biosorbent charges, biosorption onto functional groups of the biosorbents, ion exchange between rare earth ions and $\mathrm{Mg}$ and $\mathrm{K}$ present on the biosorbent sites and, surface complexation within hydroxide forms of rare earth ions and biosorbents; occurring simultaneously. In addition the sharing of the same biosorbent adsorptive sites by all the rare earth ions tested results in the low maximum biosorption density observed.

Moreover, $\mathrm{pH}$ and temperature had slight effect on desorption process of rare earth ions resulting on high desorption percentage. The kinetics of REEs desorption were fast 
429 with less than 10 min to reach terminal extraction regardless of acid type via bath agitation.

430 The extraction efficiency of REEs from parachlorella biosorbents adsorbed sites at $30^{\circ} \mathrm{C}$

431 using $\mathrm{HCl}, \mathrm{H}_{2} \mathrm{SO}_{4}, \mathrm{HNO}_{3}$ followed the order $\mathrm{HNO} 3>\mathrm{H}_{2} \mathrm{SO}_{4}>\mathrm{HCl}$ with dried and $350^{\circ} \mathrm{C}$

432 carbonized parachlorella and $\mathrm{HNO}_{3} \geq \mathrm{HCl}>\mathrm{H}_{2} \mathrm{SO}_{4}$ when using $250^{\circ} \mathrm{C}$ carbonized

433 parachlorella.

\section{Acknowledgements}

Financial support from the Ministry of Education, Culture, Sports, Science and

436 Technology of Japan is greatfully acknoledged. A special thanks is adressed to Mrs. Akira

437 Nomura and others students for various support. This work was partially supported by JST

438 Crest of Innovative Technology and System for Sustainable Water Use Research area

439 (Shibusawa group), The Global Center of Excellence, and JSPS Scientific Research (A), $440 \quad \mathrm{~N}_{0} .22246118$.

$441 \quad$ References

442 [1] G. A. Moldoveanu, V. G. Papangelakis, Recovery of rare earth elements adsorbed on 443 clay minerals: I. Desorption mechanism, Hydrometall. 117-118(2012)71-78.

444 [2] IAMGOLD corporation. Rare earth elements 101. April 2012. 445 http://www.iamgold.com/files/REE101_April_2012.pdf/2013/3/15.

446 [3] S. Cotton, Lanthanide and actinide chemistry, John Wiley\&Sons Ltd; U.K, 2006.

447 [4] J. G. Sengupta, Determination of scandium, yttrium and lanthanides in silicate rocks 448 and four new Canadian iron-formation reference materials by flame atomic449 absorption spectrometry with micro sample injection, Talanta 31(1984)1045-1051. 
450 [5] J. S. Kim, C. H. Lee, S. H. Han, M. Y. Suh, Studies on complexation and solvent

451

452

453

454

455

456

457

458

459

460

461

462

463

464

465

466 extraction of lanthanides in the presence of diaza-18-crown-6-di-isopropionic acid. Talanta 45(1997) 437-444.

[6] C. H. Xiong, Sorption behavior of D155 resin for Ce(III), Ind. J. Chem. 47(2008) 13771380.

[7] C. H. Xiong, Z. W. Zheng, Evaluation of D113 cation exchange resin for the removal of Eu(III) from aqueous solution, J. Rare Earth 28(2010) 862-867.

[8] G. M. Ritcly, A. W. Ashbrook, Solvent extraction: principle and applications to process metallurgy, partI, Elsevier press, Amsterdam 1984.

[9] O. Samuelson, Ion exchangers in analytical chemistry, New York 1972.

[10] L. Philip, L. Iyengar , C. Venkobabachar, Biosorption of U, La, Pr, Nd, Eu, and Dy by pseudomonas aeruginosa, J. Ind. Micro. Biotech. 25(2000)1-7.

[11] G. I. Karavailo, A. S. Kareva, Z.A. Avakian, V. I. Zakharova, A. A. Korenevsky, Biosorption of scandium and yttrium from solutions, Biotech let. 18(1996) 12911296.

[12] A. V. Bridgwater, Review of fast pyrolysis of biomass and product upgrading,

Biomass and Bioenergy 38(2012) 68-94. 
467 [13] R. B. Gupta, Gasoline, Diesel and ethanol biofuels from grasses and plants, Cambridge, 4682010.

469 [14] L. Wei, Y. Kunbin, P. Jinhui, Z. Libo, G. Shenghui, and X. Hongying, Effects of 470 carbonization temperatures on characteristics of porosity in coconut shell chars and 471 activated carbons derived from carbonized coconut shell chars, Ind. Crop. Prod. 28 (2008) 472 190-198.

473 [15] T.R. Nunn, J. B. Howard, J. P. Longwell, W. A. Peters, T.R. Nunn, J. B. Howard, J. P. 474 Longwell, W. A. Peters, Product compositions and kinetics in the rapid pyrolysis of sweet 475 gum hardwood, Ind. Eng. Chem. Process Des. Dev. 24 (1985) 836-844.

476 [16]J. Ponou, J. Kim, L. P. Wang, G. Dodbiba, T. Fujita, Sorption of Cr(VI) anions in 477 aqueous solution using carbonized or dried pineapple leaves, Chem. Eng. 172(2011) 906478913.

479 [17]R. C. Oliveira, C. Jouannin, E. Guibal, O. Garcia Jr, samarium(III) and 480 praseodymium(III) biosorption on sagassum sp.: batch study, Proc. Biotech. 46(2011) 736481744.

482 [18]N. Bagheri, J. Abedi, Preparation of high surface area activated carbon from corn by 483 chemical activation using potassium hydroxide, Chem. Eng. Res. Des. 87(2009) 1059-1064.

484 [19] J. R. Memon ,S.Q. Memon, M. I. Bhanger, G. Z. Memon, A. El-Turki, G.C. Allen, 485 Characterization of banana peel by scanning electron microscopy and FT-IR spectroscopy and its 486 use for cadmium removal, Col. Surf. B. 66(2008) 260-265. 
487 [20]O.I.M. Ali, H.H. Osman, S.A. Sayed, M.E.H. Shalabi, The removal of some rare earth elements 488 from their aqueous solutions on by-pass cement dust (BCD), J. Hazard. Mat. 195(2011)62-67.

489 [21]M. Atanassovaa, Synergistic solvent extraction and separation of lanthanide(III) ions with 4490 benzoyl-3-phenyl-5-isoxazolone and the quaternary ammonium salt, Solvent Extr. Ion Exch. $491 \quad 27(2009) 159-171$.

492 [22] C. Qing, Study on the adsorption of lanthanum(III) from aqueous solution by bamboo 493 charcoal, J. Rare Earth 28(2010) 125-131.

494 [23] K. Vijayaraghavan, M. Sathishkumar, R. balasubramanian, Interaction of rare earth 495 elements with a brown marine alga in multi-component solutions, Desalination $496 \quad 265(2011) 54-59$.

497 [24] M. C. Palmieri, B. Volesky, O. Garcia Jr, Biosorption of lanthanum using sagarssum 498 fluitans in bach system, Hydrometal. 67(2002) 31-36.

499 [25] E. Tertre, G. Berger, E.Simoni, S. Castet, E. Giffaut, M. Loubet, H. Catalette, 500 Europium retention onto clay minerals from 25 to $150^{\circ} \mathrm{C}$ : Experimental measurements, 501 spectroscopic features and sorption modelling, Geochim. Cosmochim. Acta 70 (2006) $502 \quad 4563-4578$.

503 [26] N. Das, D. Das, Recovery of rare earth metals through biosorption: an overview, J. 504 Rare Earth 31(2013) 933-943.

505 [27] B. Singha, S. K. Das, Biosorption of Cr(VI) ions from aqueous solution: Kinetics, 506 equilibrium, thermodynamics and desorption studies, Col. Surf. B 84(2011) 221-232. 
507 [28] P. Atkin, Akkins’ physical chemistry, ninth edition, Oxford, New York, 2010.

508

509 [29]M.M. Benjamin, Water chemistry, first edition, Mc Graw-Hill series in water resources 510 and environmental engineering, 2002.

511 [30]G. A. Moldoveanu, V. G. Papangelakis, Recovery of rare earth elements adsorbed on 512 clay minerals: II. Leaching with ammonium sulfate, Hydromett. 131-132(2013)158-166.

513 [31] M. H. Bradbury, B. Baeyens, H. Geckeis, T. Rabung, Sorption of Eu(III)/Cm(III) on 514 Ca-montmorillonite and Na-illite. Part 2: Surface complexation modelling, Geochim. 515 Cosmochim. Acta 69(2005) 5403-5412.

516 [32] O. L. Gaskova, M. B. Bukaty, Sorption of different cations onto clay minerals: 517 Modelling approach with ion exchange and surface complexation, Phys. Chem. Earth $518 \quad 33(2008) 1050-1055$.

519 [33] F. Coppin, G. Berger, A. Bauer, S. Castet, M. Loubet, Sorption of lanthanides on 520 smectite and kaolinite, Chem. Geol. 182(2002)57-68. 


\section{List of figures}
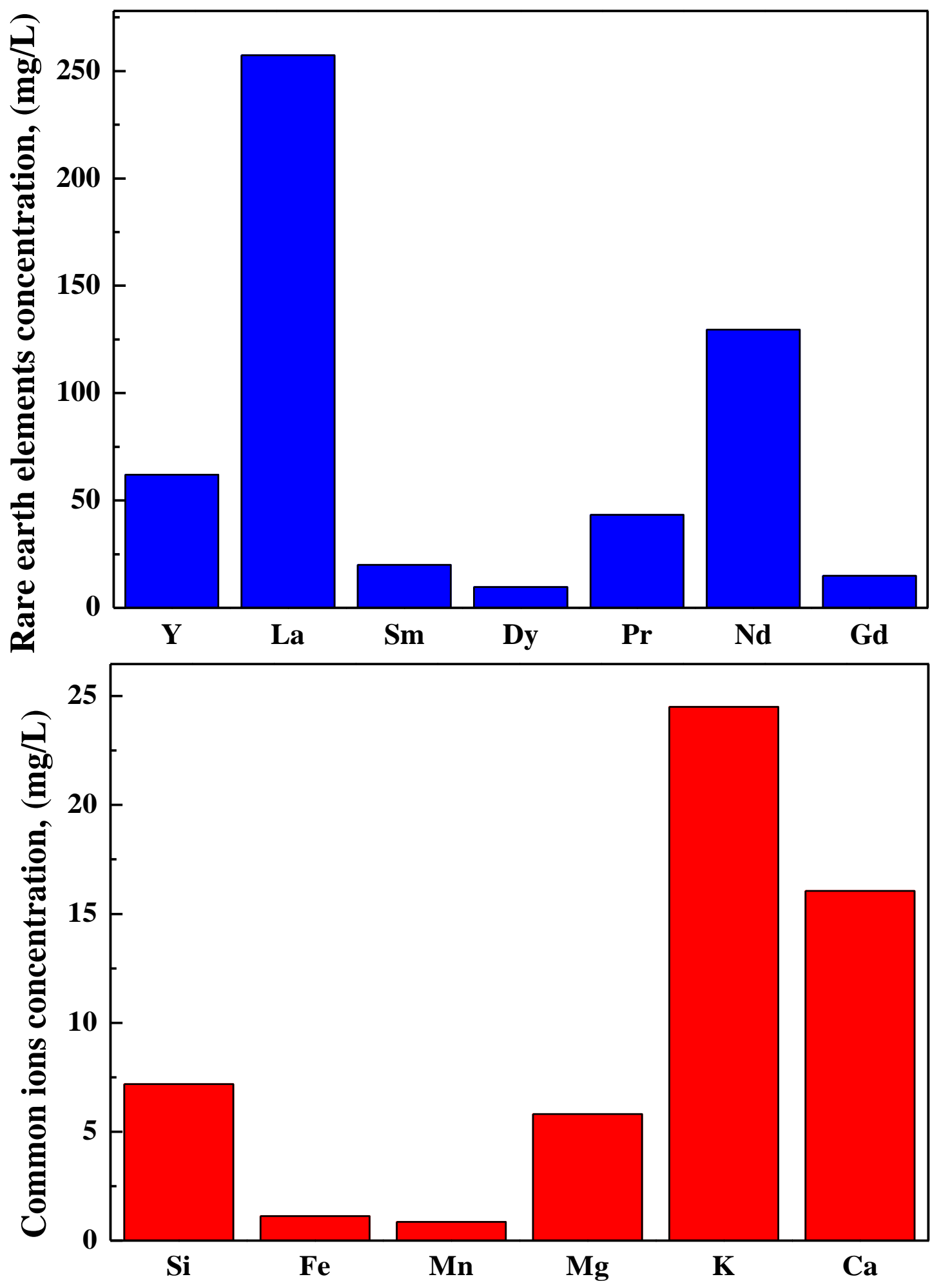

Fig.1. Vietnamese rare earth aqueous solution composition 


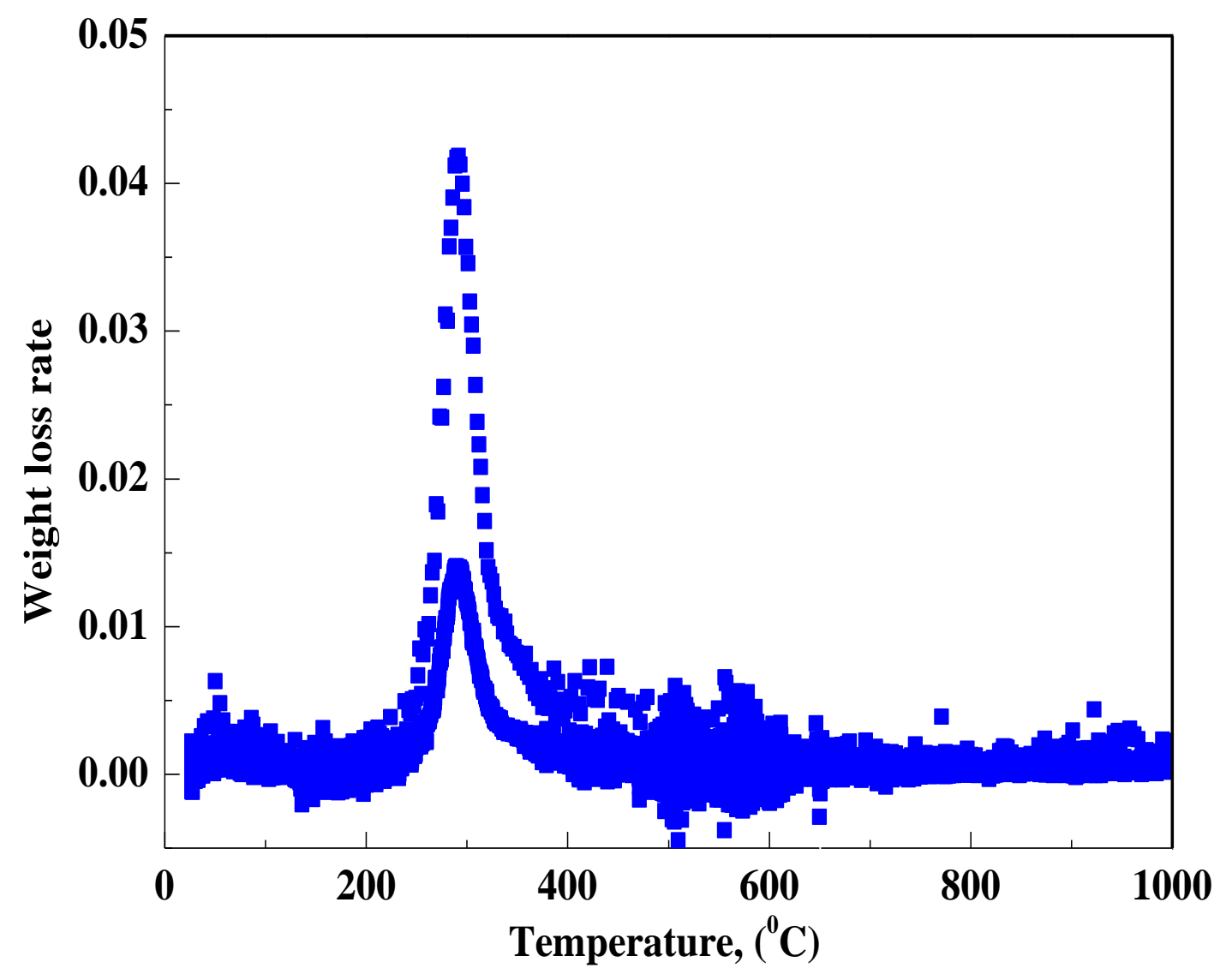

Fig.2. Thermal decomposition of parachlorella under nitrogen flow $(15 \mathrm{~L} / \mathrm{min})$ 


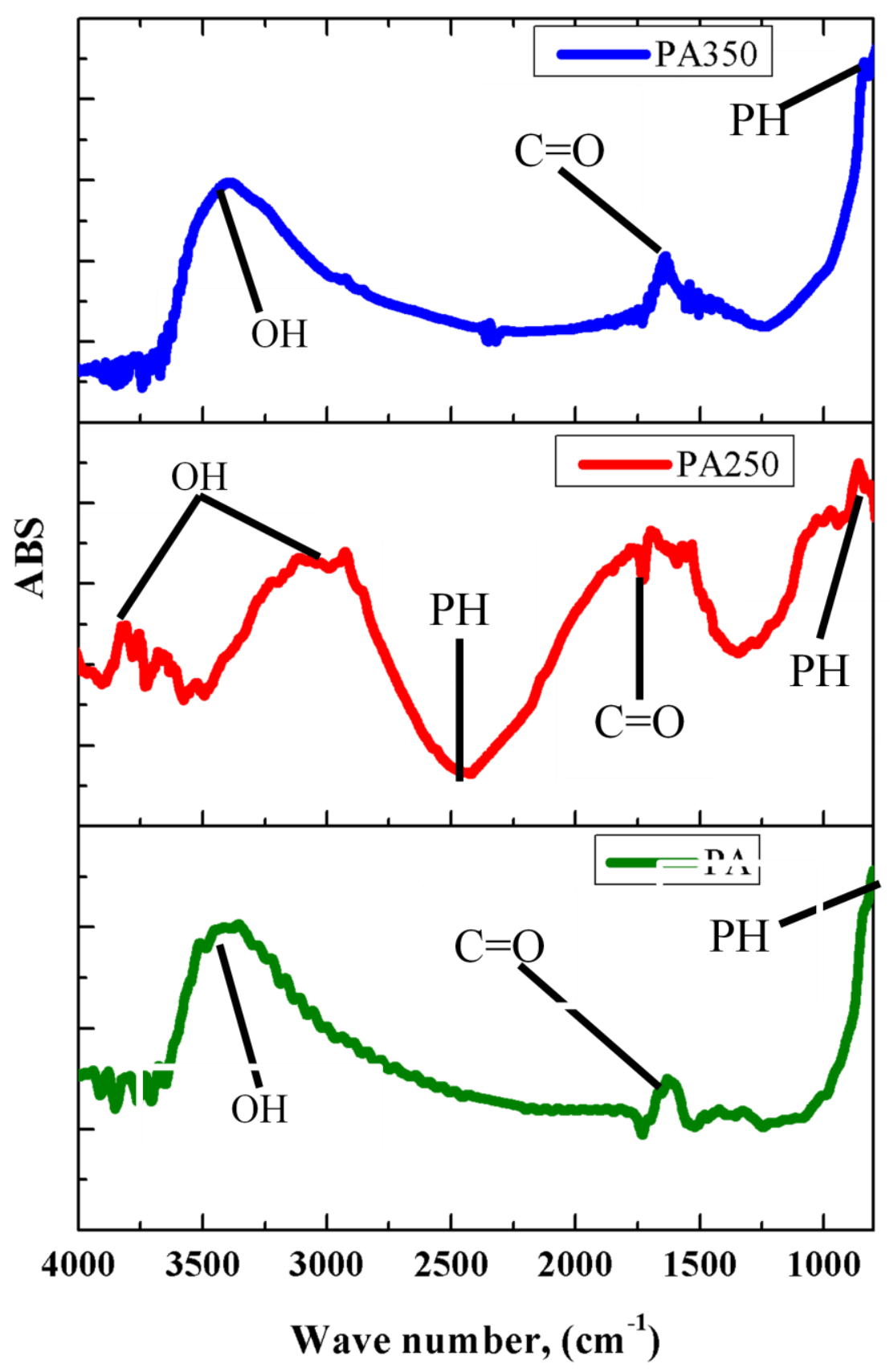

Fig.3. FT-IR results of parachlorella by-products 

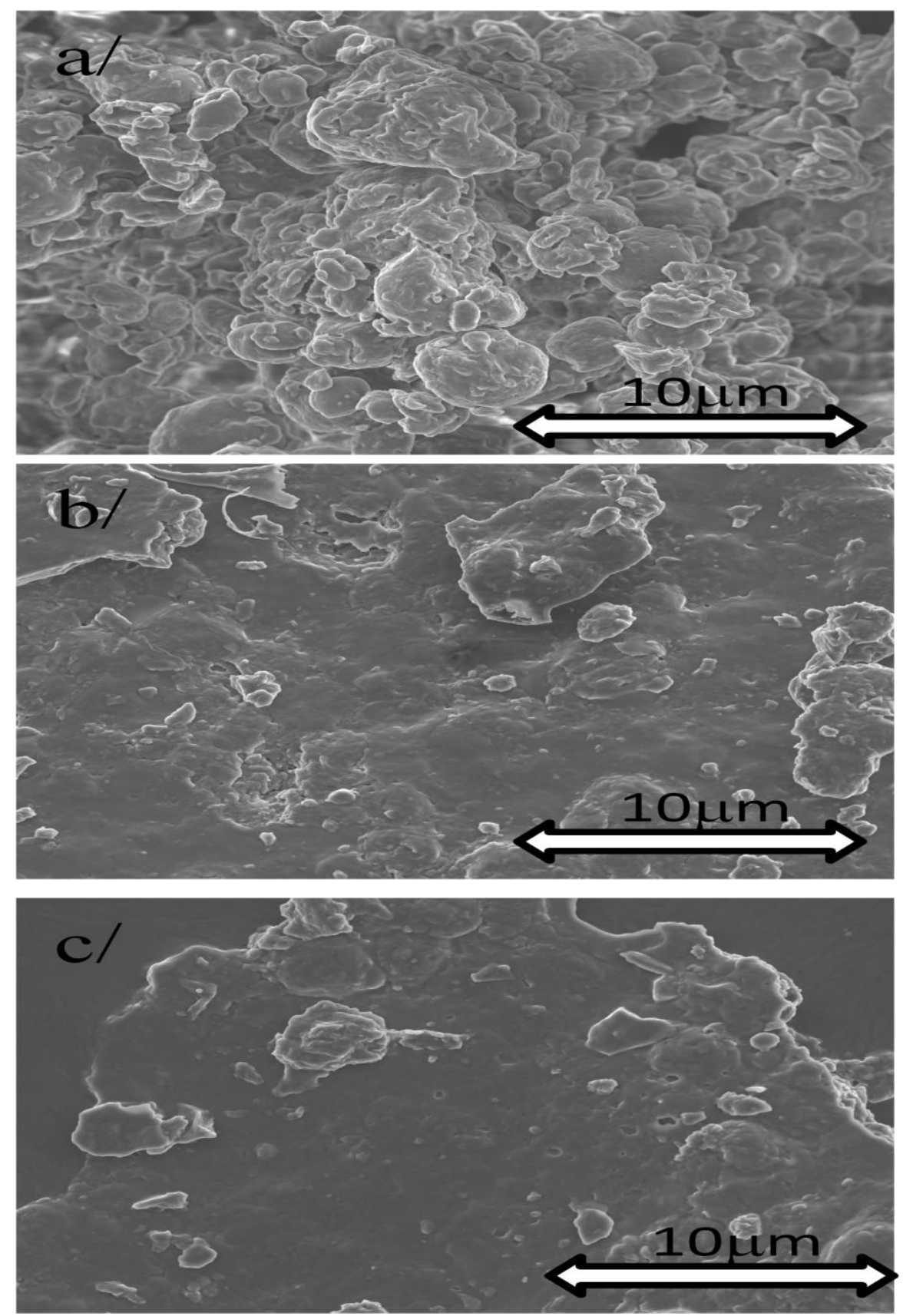

Fig.4. Scan Electromagnetic images of a/ dried (PA) and b/ $250^{\circ} \mathrm{C}(\mathrm{PA} 250)$ or $\mathrm{c} / 350^{\circ} \mathrm{C}(\mathrm{PA} 350)$ carbonized parachlorella. 

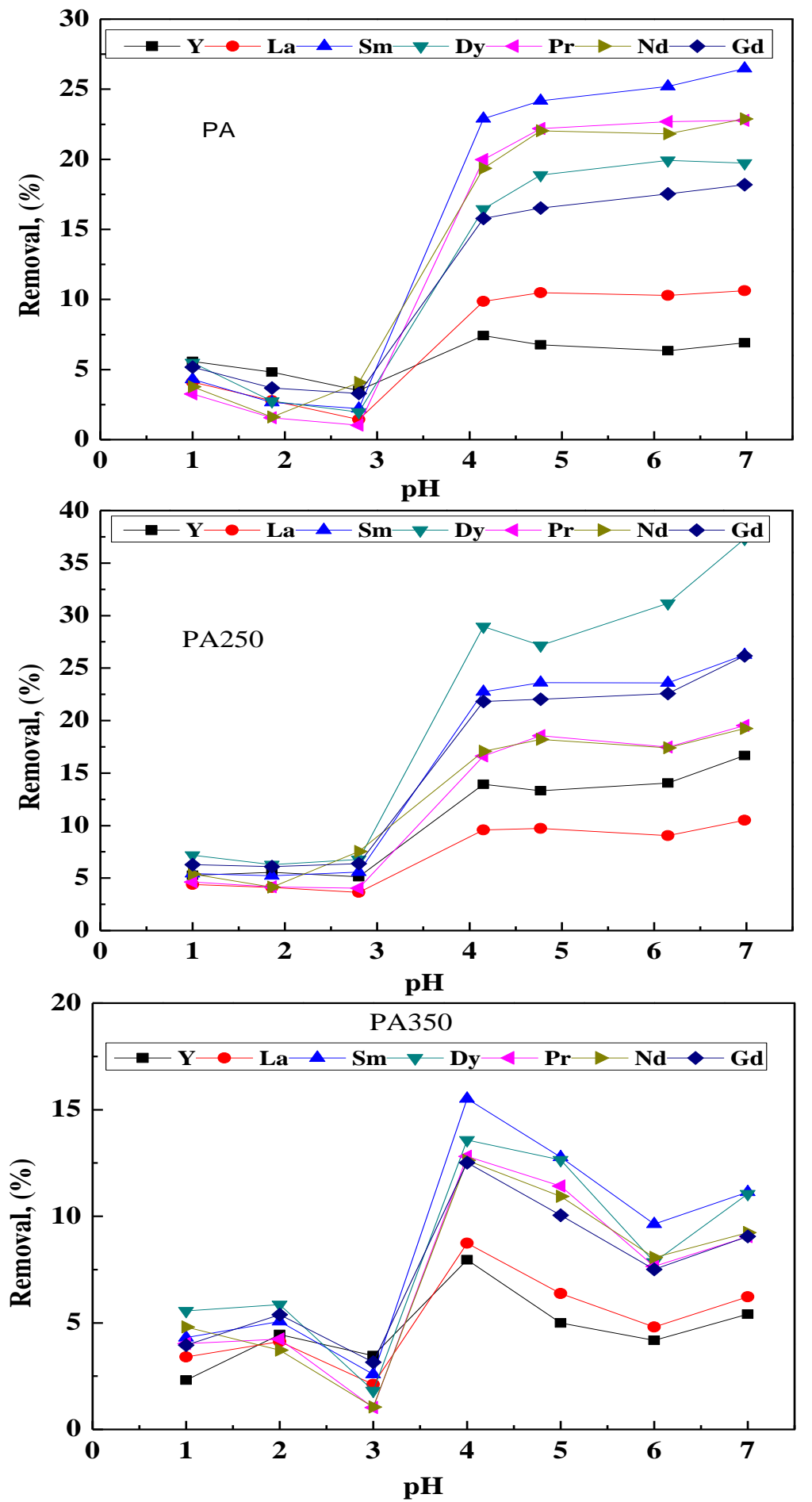

Fig.5: Effect of $\mathrm{pH}$ on dried (PA) and $250^{\circ} \mathrm{C}$ (PA250) or $350^{\circ} \mathrm{C}$ (PA350) carbonized parachlorella. Adsorbent dosage: $5 \mathrm{~g} / \mathrm{L}$; Solution temperature $30^{\circ} \mathrm{C} ; \mathrm{pH}$ range $1-7$, contact time $1 \mathrm{~h}$. 


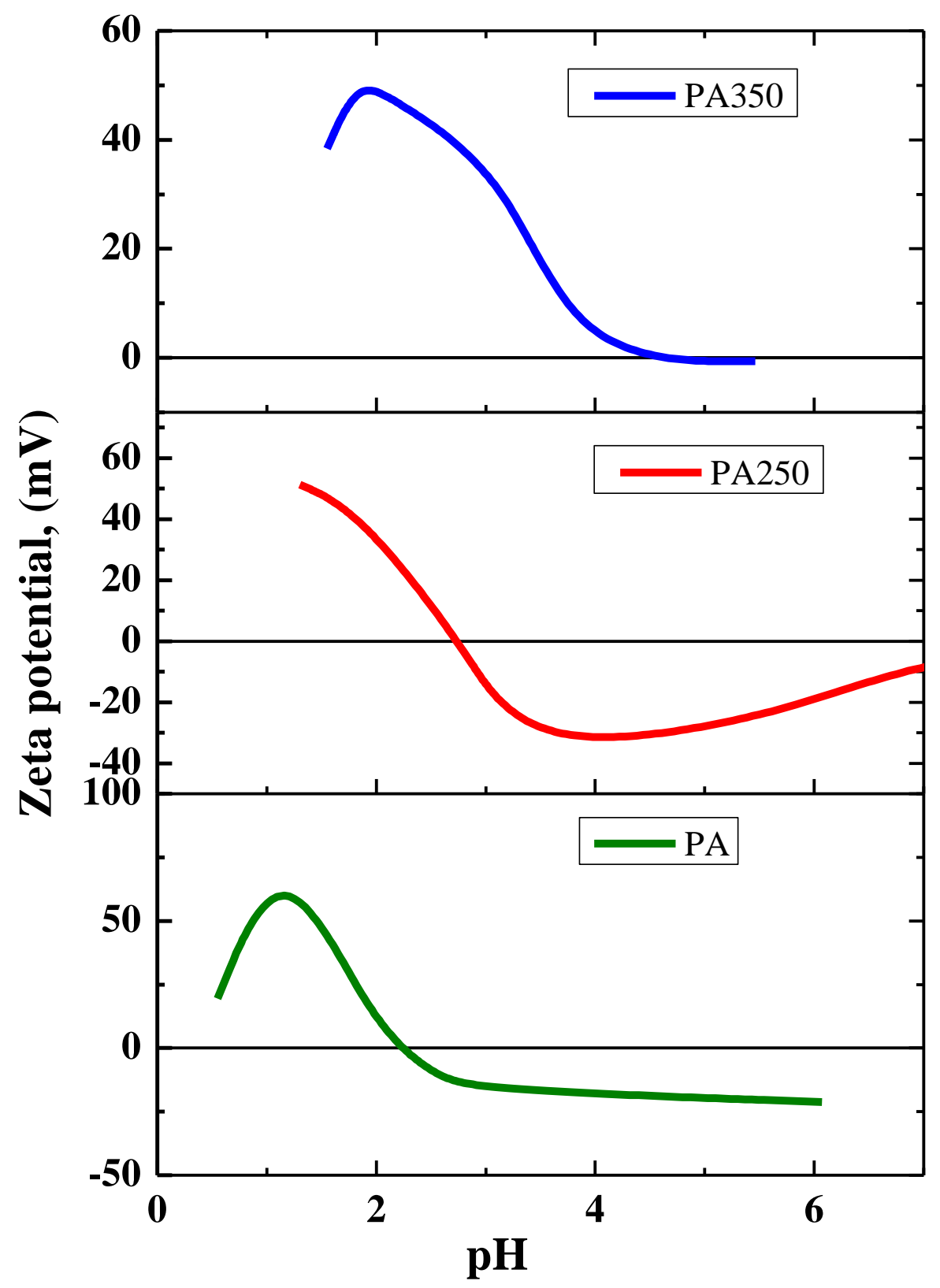

Fig.6. Zeta potential of on dried (PA) and $250^{\circ} \mathrm{C}(\mathrm{PA} 250)$ or $350^{\circ} \mathrm{C}(\mathrm{PA} 350)$ carbonized parachlorella 

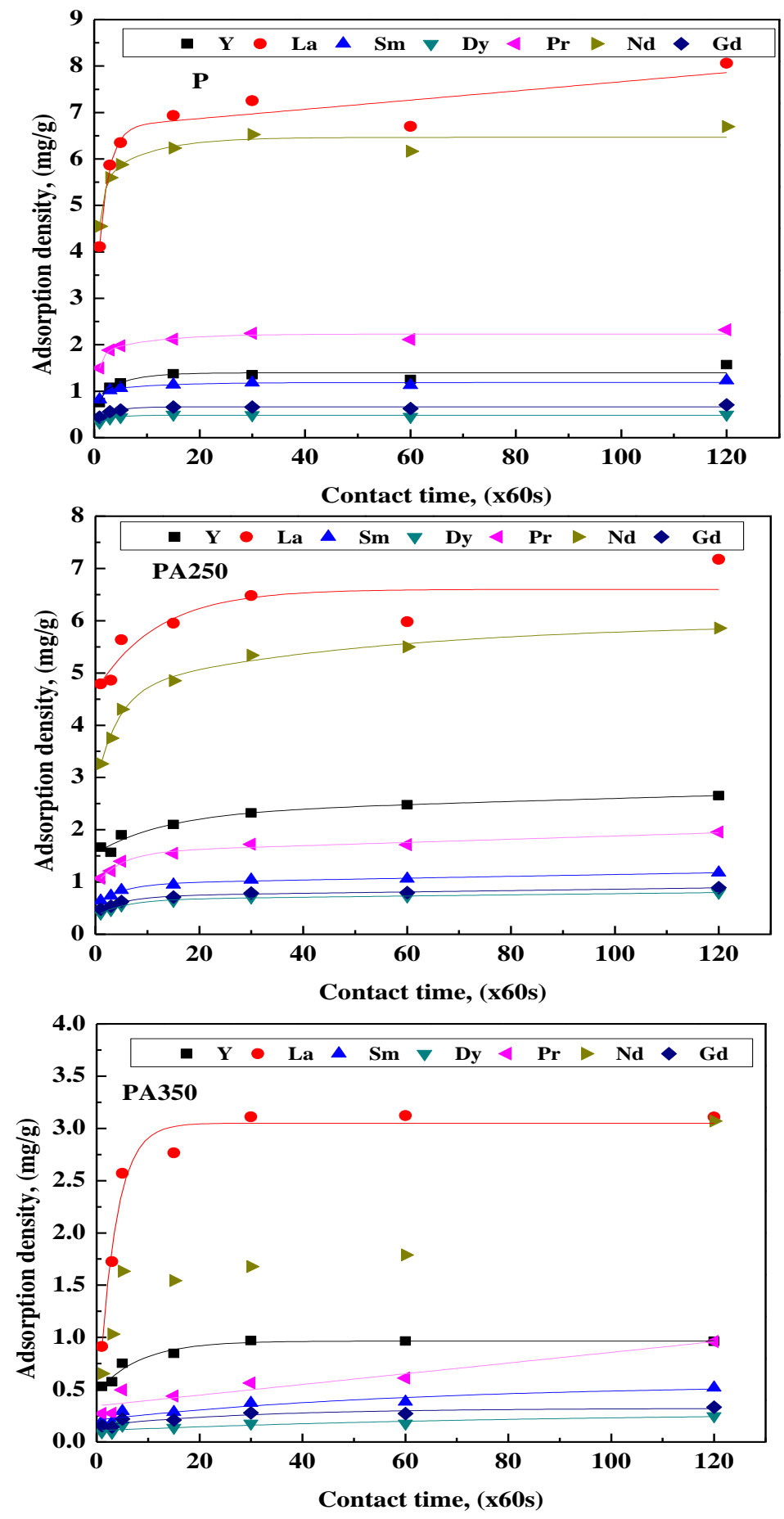

Fig.7. Effect of contact time on REEs: Adsorbent dosage: $5 \mathrm{~g} / \mathrm{L}$; Solution temperature $30^{\circ} \mathrm{C}$; initial $\mathrm{pH}+6.94$. 

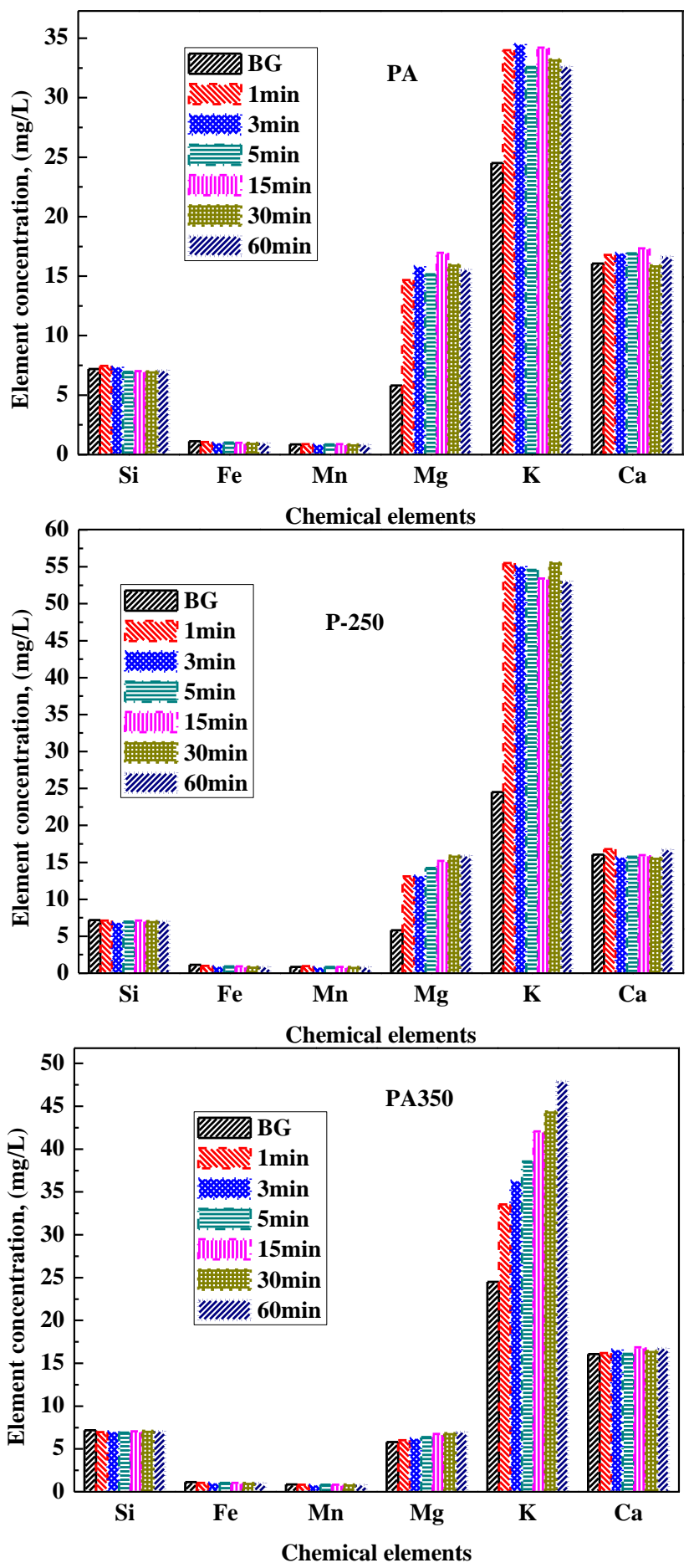

Fig.8. Effect of contact time on common ions: Adsorbent dosage: $5 \mathrm{~g} / \mathrm{L}$; Solution temperature $30^{\circ} \mathrm{C}$; initial $\mathrm{pH}+6.94 \mathrm{~N}$.B. $\mathrm{BG}$ design back ground: concentration of the element in the initial solution 


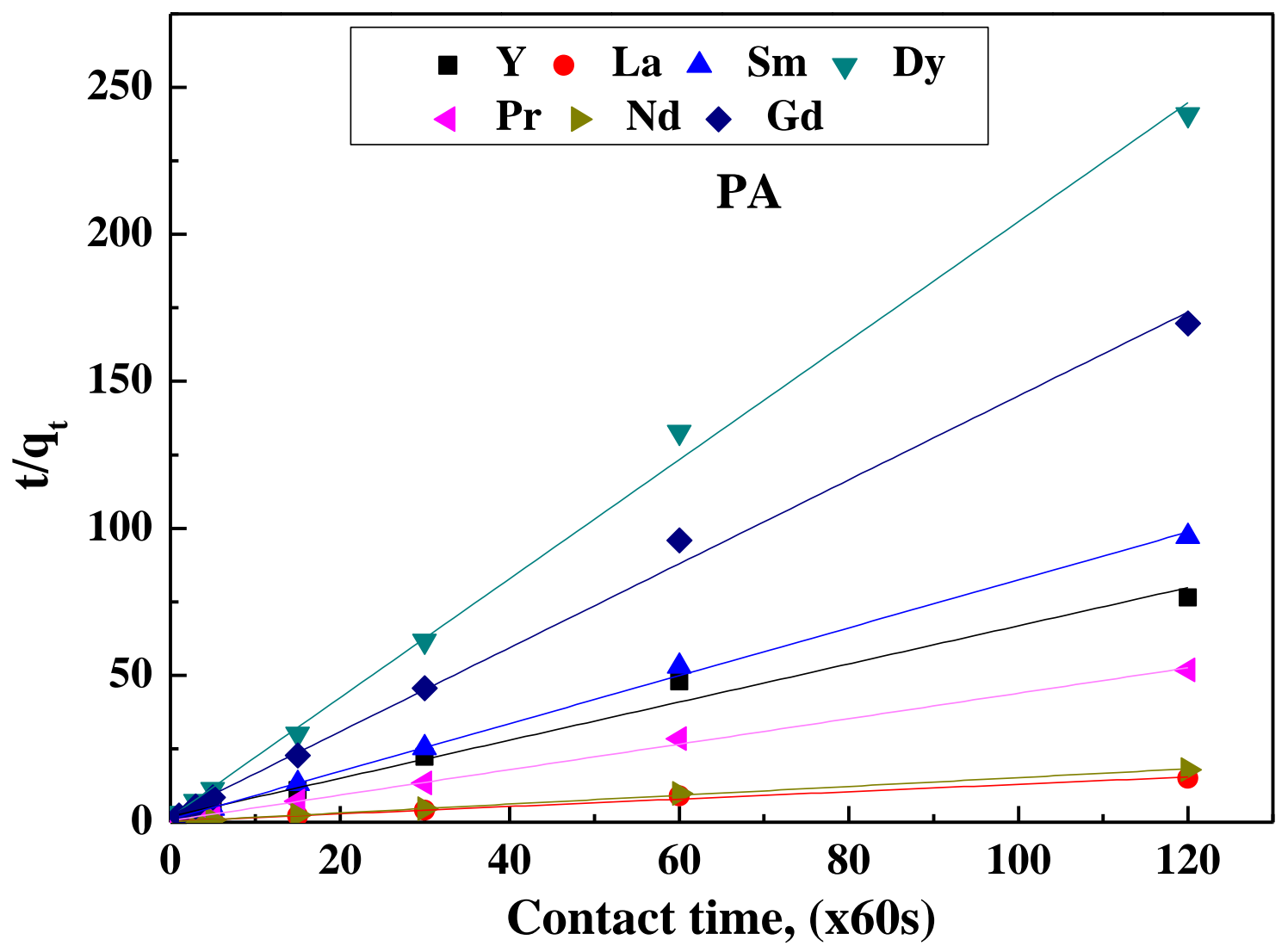

Fig.9. $2^{\text {nd }}$ order kinetics model of dried parachlorella: Adsorbent dosage: $5 \mathrm{~g} / \mathrm{L}$; Solution temperature $30^{\circ} \mathrm{C}$; initial $\mathrm{pH}=6.94$. 

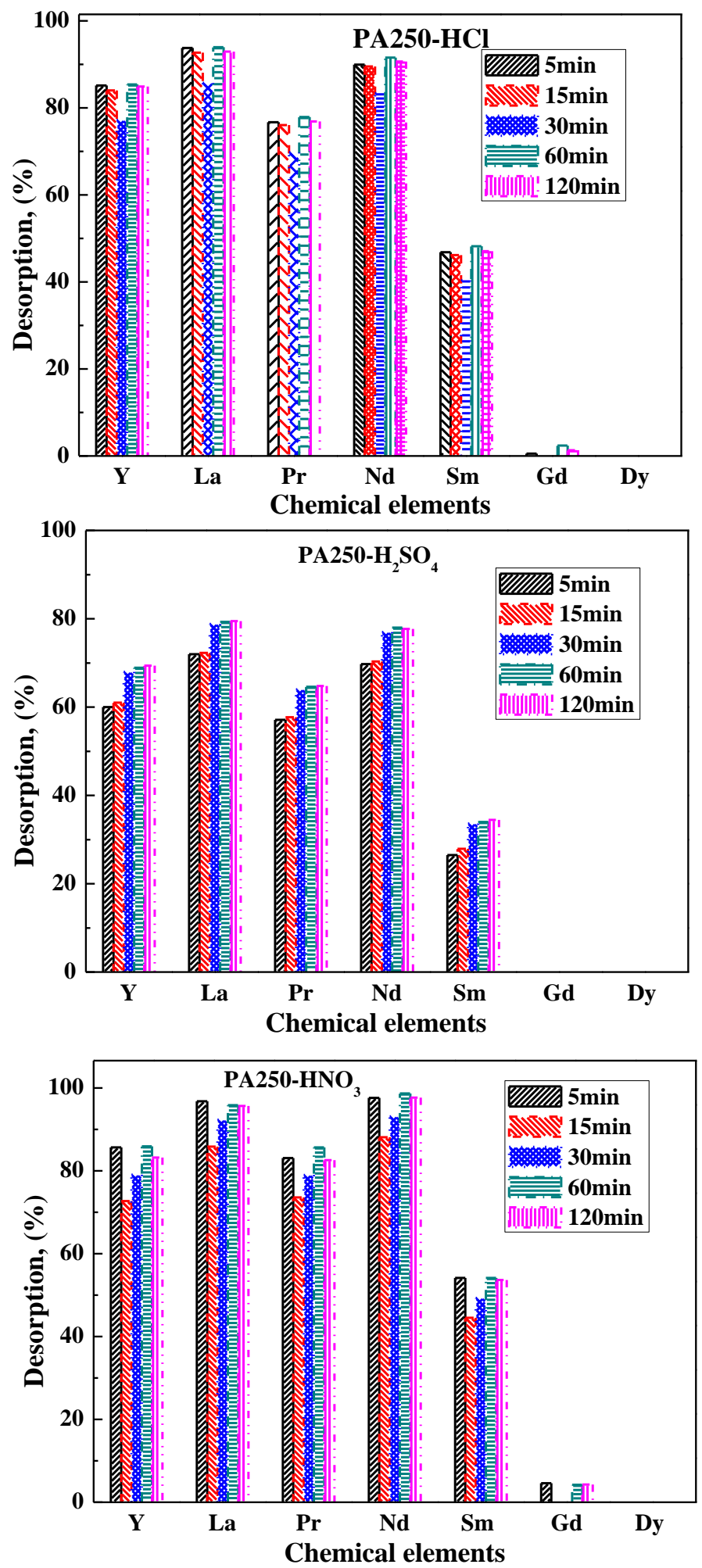

Fig.10. Effect of contact time on desorption process using $250^{\circ} \mathrm{C}$ carbonized parachlorella 


\section{List of tables}

Table 1: X-Ray fluorescence of dried (PA) and $250^{\circ} \mathrm{C}(\mathrm{PA} 250)$ or $350^{\circ} \mathrm{C}$ (PA350) carbonized parachlorella

\begin{tabular}{llll}
\hline & & Weight percentage of atoms (\%) \\
Atom & PA & PA250 & PA350 \\
\hline $\mathrm{Mg}$ & 1.12 & 0.89 & 0.965 \\
$\mathrm{Al}$ & 1.11 & 2.20 & 0.0862 \\
$\mathrm{Si}$ & 7.17 & 3.62 & 1.735 \\
$\mathrm{P}$ & 29.45 & 18.30 & 22.35 \\
$\mathrm{~S}$ & 13.55 & 6.70 & 3 \\
$\mathrm{Cl}$ & 0.54 & 0.18 & 0.105 \\
$\mathrm{~K}$ & 35.20 & 64.55 & 70 \\
$\mathrm{Ca}$ & 3.46 & 1.69 & 1.17 \\
$\mathrm{Fe}$ & 3.23 & 1.90 & 0.655 \\
$\mathrm{Cu}$ & 3.17 & - & - \\
$\mathrm{Zn}$ & 0.68 & - & - \\
$\mathrm{Ag}$ & 0.38 & - & \\
\hline
\end{tabular}


Table 2: Kinetics parameters of dried (PA) and $250^{\circ} \mathrm{C}(\mathrm{PA} 250)$ or $350^{\circ} \mathrm{C}(\mathrm{PA} 350)$ carbonized parachlorella

\begin{tabular}{|c|c|c|c|c|c|c|c|c|}
\hline \multirow[t]{2}{*}{ Ads. } & \multirow[t]{2}{*}{$\begin{array}{l}\text { Chem. } \\
\text { elem. }\end{array}$} & \multicolumn{5}{|c|}{ Pseudo ${ }^{\text {st }}$ order parameters } & \multicolumn{2}{|c|}{$\begin{array}{l}\text { Pseudo } 2^{\text {nd }} \text { order } \\
\text { parameters }\end{array}$} \\
\hline & & $\begin{array}{c}q_{e} \\
(\mathrm{mg} / \mathrm{g})\end{array}$ & $K_{1}$ & $q_{\text {e1calc }}$ & $R^{2}$ & $K_{2}$ & $q_{\text {e2calc }}$ & $R^{2}$ \\
\hline \multirow{7}{*}{ PA } & $\mathrm{Y}$ & 1.57 & 0.03 & $0.44 \pm 0.26$ & 0.04 & 0.21 & $1.54 \pm 0.16$ & 0.98 \\
\hline & $\mathrm{La}$ & 8.06 & 0.03 & $2.10 \pm 1.21$ & 0.14 & 0.05 & $7.95 \pm 0.66$ & 0.99 \\
\hline & $\operatorname{Pr}$ & 2.32 & 0.05 & $0.41 \pm 0.34$ & 0.19 & 0.33 & $2.31 \pm 0.09$ & 0.99 \\
\hline & $\mathrm{Nd}$ & 6.70 & 0.05 & $0.98 \pm 0.89$ & 0.15 & 0.14 & $6.66 \pm 0.24$ & 0.99 \\
\hline & $\mathrm{Sm}$ & 1.23 & 0.05 & $0.20 \pm 0.15$ & 0.21 & 0.67 & $1.23 \pm 0.05$ & 0.99 \\
\hline & Gd & 0.71 & 0.04 & $0.13 \pm 0.09$ & 0.08 & 0.90 & $0.70 \pm 0.04$ & 0.99 \\
\hline & Dy & 0.50 & 0.05 & $0.08 \pm 0.09$ & 0.01 & 2.31 & $0.49 \pm 0.02$ & 0.99 \\
\hline \multirow{7}{*}{ PA250 } & Y & 2.66 & 0.07 & $0.97 \pm 0.17$ & 0.95 & 0.13 & $2.68 \pm 0.10$ & 0.99 \\
\hline & $\mathrm{La}$ & 7.17 & 0.03 & $1.82 \pm 0.83$ & 0.27 & 0.06 & $7.08 \pm 0.58$ & 0.99 \\
\hline & $\operatorname{Pr}$ & 1.95 & 0.05 & $0.67 \pm 0.24$ & 0.68 & 0.17 & $1.95 \pm 0.11$ & 0.99 \\
\hline & $\mathrm{Nd}$ & 5.86 & 0.08 & $2.01 \pm 0.66$ & 0.86 & 0.07 & $5.91 \pm 0.16$ & 0.99 \\
\hline & $\mathrm{Sm}$ & 1.18 & 0.06 & $0.42 \pm 0.13$ & 0.79 & 0.30 & $1.19 \pm 0.05$ & 0.99 \\
\hline & $\mathrm{Gd}$ & 0.89 & 0.06 & $0.32 \pm 0.11$ & 0.75 & 0.38 & $0.90 \pm 0.05$ & 0.99 \\
\hline & Dy & 0.80 & 0.07 & $0.30 \pm 0.11$ & 0.80 & 0.43 & $0.80 \pm 0.03$ & 0.99 \\
\hline \multirow{7}{*}{ PA350 } & Y & 0.97 & 0.09 & $3.97 \pm 3.53$ & 0.68 & 0.76 & $0.98 \pm 0.02$ & 0.99 \\
\hline & $\mathrm{La}$ & 3.12 & 0.09 & $1.74 \pm 0.49$ & 0.46 & 0.18 & $3.17 \pm 0.05$ & 0.99 \\
\hline & $\operatorname{Pr}$ & 0.96 & 0.02 & $39.29 \times 10^{4} \pm 41.25 \times 10^{7}$ & 0.65 & 0.09 & $0.96 \pm 0.25$ & 0.91 \\
\hline & $\mathrm{Nd}$ & 3.07 & 0.02 & $63.89 \pm 93.04 \times 10^{1}$ & 0.39 & 0.03 & $2.98 \pm 0.93$ & 0.88 \\
\hline & $\mathrm{Sm}$ & 0.52 & 0.04 & $55.22 \times 10^{5} \pm 11.09 \times 10^{9}$ & 0.74 & 0.24 & $0.52 \pm 0.08$ & 0.97 \\
\hline & $\mathrm{Gd}$ & 0.33 & 0.04 & $74.38 \times 10^{5} \pm 17.86 \times 10^{9}$ & 0.61 & 0.57 & $0.33 \pm 0.03$ & 0.99 \\
\hline & Dy & 0.25 & 0.03 & $1.65 \times 10^{14} \pm 1.67 \times 10^{22}$ & 0.51 & 0.50 & $0.25 \pm 0.04$ & 0.96 \\
\hline
\end{tabular}


Table 3: Thermodynamics parameters of dried (PA) and $250^{\circ} \mathrm{C}(\mathrm{PA} 250)$ or $350^{\circ} \mathrm{C}$ (PA350) carbonized parachlorella

\begin{tabular}{|c|c|c|c|c|}
\hline Adsorbents & REEs & $\mathrm{Ea}(K J / m o l)$ & $\Delta \mathrm{H}(\mathrm{KJ} / \mathrm{mol})$ & $\begin{array}{l}\text { Nature of the } \\
\text { reaction }\end{array}$ \\
\hline \multirow{7}{*}{ PA } & $\mathrm{Y}$ & 28.56 & 26.04 & \multirow{7}{*}{$\begin{array}{l}\text { Chemisorption } \\
\text { and endothermic } \\
\text { Chemisorption } \\
\text { and endothermic } \\
\text { Chemisorption } \\
\text { and endothermic } \\
\text { Chemisorption } \\
\text { and endothermic } \\
\text { Chemisorption } \\
\text { Chemisorption } \\
\text { and endothermic }\end{array}$} \\
\hline & $\mathrm{La}$ & 14.34 & 11.82 & \\
\hline & $\operatorname{Pr}$ & 18.05 & 15.53 & \\
\hline & $\mathrm{Nd}$ & 287.13 & 284.61 & \\
\hline & $\mathrm{Sm}$ & 0.22 & - & \\
\hline & $\mathrm{Gd}$ & 92.16 & 89.64 & \\
\hline & Dy & - & - & \\
\hline \multirow{7}{*}{ PA250 } & $\mathrm{Y}$ & - & - & \multirow{7}{*}{$\begin{array}{l}\text { Chemisorption } \\
\text { and exothermic } \\
\text { Chemisorption } \\
\text { and endothermic } \\
\text { Chemisorption } \\
\text { and endothermic } \\
\text { Chemisorption } \\
\text { and endothermic } \\
\text { Chemisorption } \\
\text { and endothermic }\end{array}$} \\
\hline & $\mathrm{La}$ & 9.28 & 6.76 & \\
\hline & $\operatorname{Pr}$ & 18.27 & 15.75 & \\
\hline & $\mathrm{Nd}$ & 20.59 & 18.07 & \\
\hline & $\mathrm{Sm}$ & 44.69 & 42.17 & \\
\hline & $\mathrm{Gd}$ & 32.42 & 29.90 & \\
\hline & Dy & - & - & \\
\hline \multirow{7}{*}{ PA350 } & $\mathrm{Y}$ & 24.40 & 21.88 & \multirow{7}{*}{$\begin{array}{l}\text { Chemisorption } \\
\text { and endothermic } \\
\text { Chemisorption } \\
\text { and endothermic } \\
\text { Chemisorption } \\
\text { and endothermic } \\
\text { Chemisorption } \\
\text { and endothermic } \\
\text { Chemisorption } \\
\text { and endothermic } \\
\text { Chemisorption } \\
\text { and endothermic } \\
\text { Chemisorption } \\
\text { and endothermic }\end{array}$} \\
\hline & $\mathrm{La}$ & 37.80 & 35.28 & \\
\hline & $\operatorname{Pr}$ & 63.62 & 61.10 & \\
\hline & $\mathrm{Nd}$ & 76.64 & 74.12 & \\
\hline & $\mathrm{Sm}$ & 128.73 & 126.21 & \\
\hline & $\mathrm{Gd}$ & 114.20 & 111.68 & \\
\hline & Dy & 60.84 & 58.32 & \\
\hline
\end{tabular}


Table 4: Langmuir parameters of dried (PA) and $250^{\circ} \mathrm{C}(\mathrm{PA} 250)$ or $350^{\circ} \mathrm{C}(\mathrm{PA} 350)$ carbonized parachlorella

\begin{tabular}{|c|c|c|c|c|}
\hline \multirow[t]{2}{*}{ Adsorbents } & \multirow{2}{*}{$\begin{array}{l}\text { Chemical } \\
\text { elements }\end{array}$} & \multicolumn{3}{|c|}{ Langmuir } \\
\hline & & $\begin{array}{c}q_{\max } \\
(\mathrm{mg} / \mathrm{g})\end{array}$ & $b$ & $R^{2}$ \\
\hline \multirow{7}{*}{$\mathrm{PA}$} & $\mathrm{Y}$ & 1.15 & 0.89 & 0.99 \\
\hline & $\mathrm{La}$ & 6.08 & 0.08 & 0.99 \\
\hline & $\operatorname{Pr}$ & 2.38 & 0.26 & 0.97 \\
\hline & $\mathrm{Nd}$ & 6.49 & 0.07 & 0.99 \\
\hline & $\mathrm{Sm}$ & 1.29 & 0.40 & 0.99 \\
\hline & $\mathrm{Gd}$ & 0.57 & 1.67 & 0.99 \\
\hline & Dy & 0.68 & 0.23 & 0.96 \\
\hline \multirow{7}{*}{ PA250 } & Y & 4.73 & 0.03 & 0.98 \\
\hline & $\mathrm{La}$ & 8.52 & 0.04 & 0.98 \\
\hline & $\operatorname{Pr}$ & 2.02 & 0.22 & 0.98 \\
\hline & $\mathrm{Nd}$ & 5.53 & 0.08 & 0.99 \\
\hline & $\mathrm{Sm}$ & 1.53 & 0.25 & 0.99 \\
\hline & $\mathrm{Gd}$ & 1.05 & 0.51 & 0.99 \\
\hline & Dy & 1.39 & 0.36 & 0.99 \\
\hline \multirow{7}{*}{ PA350 } & Y & 1.14 & 0.02 & 0.99 \\
\hline & $\mathrm{La}$ & 3.47 & 0.02 & 0.99 \\
\hline & $\operatorname{Pr}$ & 1.08 & 0.10 & 0.99 \\
\hline & $\mathrm{Nd}$ & 2.84 & 0.03 & 0.98 \\
\hline & $\mathrm{Sm}$ & 0.68 & 0.30 & 0.96 \\
\hline & $\mathrm{Gd}$ & 1.05 & 0.06 & 0.95 \\
\hline & Dy & 0.20 & 5.09 & 0.99 \\
\hline
\end{tabular}


Table 5: Desorption: effect of acid concentration; : Solution temperature $30^{\circ} \mathrm{C}$; adsorbent: adsorbate rate $0.05 \mathrm{~g} / 10 \mathrm{~mL}$; contact time $1 \mathrm{~h}$.

\begin{tabular}{|c|c|c|c|c|c|c|c|c|c|c|}
\hline \multirow{3}{*}{ Samples } & \multicolumn{10}{|c|}{ Desorption, (\%) } \\
\hline & \multicolumn{4}{|c|}{$\begin{array}{c}\mathrm{HCl} \text { concentration } \\
(\mathrm{mol} / \mathrm{L})\end{array}$} & \multicolumn{3}{|c|}{$\begin{array}{l}\mathrm{H}_{2} \mathrm{SO}_{4} \text { concentration } \\
(\mathrm{mol} / \mathrm{L})\end{array}$} & \multicolumn{3}{|c|}{$\begin{array}{c}\mathrm{HNO}_{3} \text { concentration } \\
(\mathrm{mol} / \mathrm{L})\end{array}$} \\
\hline & C.E & 0.1 & 0.5 & 1 & 0.1 & 0.5 & 1 & 0.1 & 0.5 & 1 \\
\hline \multirow{7}{*}{ PA } & $\mathrm{Y}$ & 98.81 & 75.76 & 81.20 & 70.46 & 59.46 & 45.27 & 78.37 & 75.04 & 84.53 \\
\hline & $\mathrm{La}$ & 100.00 & 100.00 & 100.00 & 100.00 & 94.18 & 82.26 & 100.00 & 100.00 & 100.00 \\
\hline & $\operatorname{Pr}$ & 100.00 & 91.95 & 98.21 & 91.03 & 83.03 & 70.51 & 97.65 & 96.89 & 100.00 \\
\hline & $\mathrm{Nd}$ & 100.00 & 100.00 & 100.00 & 100.00 & 94.51 & 81.95 & 100.00 & 100.00 & 100.00 \\
\hline & $\mathrm{Sm}$ & 74.13 & 59.76 & 65.63 & 58.56 & 50.90 & 38.39 & 64.27 & 64.28 & 76.43 \\
\hline & $\mathrm{Gd}$ & 7.33 & 0.00 & 0.00 & 0.00 & 0.00 & 0.00 & 0.00 & 0.00 & 3.21 \\
\hline & Dy & 0.00 & 0.00 & 0.00 & 0.00 & 0.00 & 0.00 & 0.00 & 0.00 & 0.00 \\
\hline \multirow{7}{*}{ PA250 } & $\mathrm{Y}$ & 78.96 & 80.60 & 83.34 & 69.77 & 67.81 & 58.18 & 78.34 & 77.04 & 77.75 \\
\hline & $\mathrm{La}$ & 94.61 & 92.60 & 96.52 & 85.53 & 83.64 & 73.22 & 94.76 & 92.89 & 95.07 \\
\hline & $\operatorname{Pr}$ & 83.36 & 81.82 & 86.03 & 74.47 & 73.79 & 62.48 & 84.59 & 85.80 & 88.35 \\
\hline & $\mathrm{Nd}$ & 97.89 & 96.12 & 100.00 & 88.72 & 87.47 & 75.84 & 98.68 & 100.00 & 100.00 \\
\hline & $\mathrm{Sm}$ & 47.93 & 48.28 & 51.77 & 40.51 & 39.54 & 29.28 & 48.66 & 52.06 & 55.32 \\
\hline & $\mathrm{Gd}$ & 0.00 & 0.00 & 0.00 & 0.00 & 0.00 & 0.00 & 0.00 & 0.00 & 0.00 \\
\hline & Dy & 0.00 & 0.00 & 0.00 & 0.00 & 0.00 & 0.00 & 0.00 & 0.00 & 0.00 \\
\hline \multirow{7}{*}{ PA350 } & $\mathrm{Y}$ & 78.44 & 67.73 & 64.54 & 64.93 & 48.14 & 40.88 & 68.42 & 62.86 & 64.55 \\
\hline & $\mathrm{La}$ & 100.00 & 93.31 & 88.47 & 92.40 & 79.36 & 74.00 & 93.48 & 88.23 & 93.07 \\
\hline & $\operatorname{Pr}$ & 79.32 & 71.84 & 67.47 & 72.50 & 61.82 & 57.84 & 71.68 & 69.37 & 74.43 \\
\hline & $\mathrm{Nd}$ & 94.34 & 86.95 & 81.70 & 86.95 & 75.30 & 71.41 & 86.54 & 83.81 & 89.63 \\
\hline & $\mathrm{Sm}$ & 42.56 & 33.71 & 29.81 & 34.89 & 23.65 & 19.15 & 34.07 & 31.01 & 36.81 \\
\hline & $\mathrm{Gd}$ & 0.00 & 0.00 & 0.00 & 0.00 & 0.00 & 0.00 & 0.00 & 0.00 & 0.00 \\
\hline & Dy & 0.00 & 0.00 & 0.00 & 0.00 & 0.00 & 0.00 & 0.00 & 0.00 & 0.00 \\
\hline
\end{tabular}

C.E: Chemical element 
Table 6: Desorption: Effect of temperature: adsorbate rate $0.05 \mathrm{~g} / 10 \mathrm{~mL}$; acid concentration $1 \mathrm{~mol} / \mathrm{L}$; contact time $1 \mathrm{~h}$.

\begin{tabular}{|c|c|c|c|c|c|c|c|c|c|c|}
\hline \multirow{3}{*}{ Samples } & \multicolumn{10}{|c|}{ Desorption, (\%) } \\
\hline & \multirow[b]{2}{*}{ T. } & \multicolumn{3}{|c|}{$\mathbf{H C l}$} & \multicolumn{2}{|l|}{$\mathrm{H}_{2} \mathrm{SO}_{4}$} & \multirow[b]{2}{*}{$7^{\circ}{ }^{\circ} \mathrm{C}$} & \multicolumn{3}{|c|}{$\mathrm{HNO}_{3}$} \\
\hline & & $30^{\circ} \mathrm{C}$ & $\mathbf{5 0}^{\circ} \mathrm{C}$ & $\mathbf{7 0}^{\circ} \mathrm{C}$ & $30^{\circ} \mathrm{C}$ & $50^{\circ} \mathrm{C}$ & & $30^{\circ} \mathrm{C}$ & $50^{\circ} \mathrm{C}$ & $\mathbf{7 0}^{\circ} \mathrm{C}$ \\
\hline \multirow{7}{*}{ PA } & $\mathbf{Y}$ & 81.20 & 76.09 & 85.23 & 45.27 & 65.84 & 63.62 & 84.53 & 80.03 & 87.93 \\
\hline & La & 100.00 & 97.10 & 100.00 & 82.26 & 88.38 & 89.50 & 100.00 & 100.00 & 100.00 \\
\hline & Pr & 98.21 & 82.32 & 100.00 & 70.51 & 75.83 & 76.21 & 100.00 & 89.96 & 100.47 \\
\hline & Nd & 100.00 & 92.30 & 100.00 & 81.95 & 85.64 & 86.25 & 100.00 & 100.00 & 100.00 \\
\hline & Sm & 65.63 & 56.18 & 74.80 & 38.39 & 49.44 & 49.22 & 76.43 & 63.88 & 74.07 \\
\hline & Gd & 0.00 & 0.00 & 8.57 & 0.00 & 0.00 & 0.00 & 3.21 & 1.74 & 9.81 \\
\hline & Dy & 0.00 & 0.00 & 0.00 & 0.00 & 0.00 & 0.00 & 0.00 & 0.00 & 0.00 \\
\hline \multirow{7}{*}{ PA250 } & $\mathbf{Y}$ & 83.34 & 82.13 & 91.78 & 58.18 & 73.97 & 70.93 & 77.75 & 86.62 & 89.68 \\
\hline & La & 96.52 & 90.08 & 100.00 & 73.22 & 85.91 & 83.95 & 95.07 & 99.62 & 100.00 \\
\hline & Pr & 86.03 & 74.11 & 87.06 & 62.48 & 70.84 & 70.07 & 88.35 & 85.70 & 91.11 \\
\hline & Nd & 100.00 & 85.87 & 99.62 & 75.84 & 82.65 & 82.77 & 100.00 & 99.72 & 100.00 \\
\hline & Sm & 51.77 & 45.68 & 57.72 & 29.28 & 41.61 & 40.82 & 55.32 & 57.11 & 61.95 \\
\hline & Gd & 0.00 & 0.00 & 7.76 & 0.00 & 0.00 & 0.00 & 0.00 & 6.33 & 7.67 \\
\hline & Dy & 0.00 & 0.00 & 0.00 & 0.00 & 0.00 & 0.00 & 0.00 & 0.00 & 0.00 \\
\hline \multirow{7}{*}{ PA350 } & $\mathbf{Y}$ & 64.54 & 46.37 & 45.10 & 40.88 & 49.88 & 39.93 & 64.55 & 51.93 & 95.46 \\
\hline & La & 88.47 & 77.22 & 73.81 & 74.00 & 79.80 & 70.32 & 93.07 & 83.80 & 100.00 \\
\hline & Pr & 67.47 & 58.53 & 44.48 & 57.84 & 60.59 & 53.97 & 74.43 & 65.26 & 100.00 \\
\hline & Nd & 81.70 & 73.19 & 69.51 & 71.41 & 73.20 & 67.73 & 89.63 & 81.35 & 94.80 \\
\hline & Sm & 29.81 & 18.79 & 4.39 & 19.15 & 20.78 & 14.57 & 36.81 & 25.95 & 100.00 \\
\hline & Gd & 0.00 & 0.00 & 0.00 & 0.00 & 0.00 & 0.00 & 0.00 & 0.00 & 0.00 \\
\hline & Dy & 0.00 & 0.00 & 0.00 & 0.00 & 0.00 & 0.00 & 0.00 & 0.00 & 0.00 \\
\hline
\end{tabular}

